\title{
IDEA PENTARCHII JAKO RĘKOJMIA JEDNOŚCI KOŚCIOLA W DOBIE IKONOKLAZMU. Stanowisko Teodora Studyty
}

W 1. poł VIII w. Kościół bizantyński został dotknięty przez kryzys związany z ikonoklazmem, który przez ponad sto lat podzielił chrześcijan Wschodu na dwa zwalczające się stronnictwa. Do eskalacji konfliktu doszło, w początkowej fazie, w czasie, gdy patriarchą Konstantynopola był Germanos. Spotkał się on z niechęcią do kultu obrazów części społeczeństwa, w tym szczególnie ze strony wysokich dostojników kościelnych. Ruch ikonoklastyczny stał się bardziej aktywny, gdy przeciwnicy obrazów znaleźli poparcie cesarza Leona III (717-741). W 726 r. cesarz wydał pierwszy edykt przeciwko czci oddawanej ikonie. W styczniu 730 r. cesarz zwołał zebranie najwyższych hierarchów świeckich i duchownych, na którym ponownie oficjalnie wystąpił przeciwko kultowi obrazów. Patriarcha Germanos, który nie zgodził się na podpisanie cesarskiego edyktu, został zmuszony do złożenia urzędu. Jego ikonoklastyczny następca Anastazy zredagował i podpisał dokument przekazany natychmiast papieżowi Grzegorzowi II w postaci listu synodalnego. Podjęte decyzje doprowadziły do zerwania stosunków między Konstantynopolem a Rzymem¹.

Następca cesarza Leona III, Konstantyn V (741-775), także gorliwy zwolennik ikonoklazmu, zredagował zbiór Zapytań, który stanowił pierwszy zarys teologii ikonoklastycznej. W styczniu 754 r. cesarz zwołał ikonoklastyczny synod w Hiereia. Biskupi przybyli na synod nadali zgromadzeniu tytuł „soboru powszechnego". Po przyjęciu definicji wiary zostało zwołane publiczne posiedzenie w kościele w Blachernach w celu jej odczytania².

Po śmierci Leona IV (775-780), następcy Konstantyna V, w 780 r. regencję przejęła Irena, żona Leona IV, która pragnęła przywrócić kult obra-

* Dr Oleksandr Kashchuk - adiunkt w Katedrze Filologii Klasycznej na Wydziale Języków Obcych Uniwersytetu im. Iwana Franki we Lwowie oraz starszy wykładowca w Katedrze Teologii na Wydziale Filozoficzno-Teologicznym Ukraińskiego Katolickiego Uniwersytetu we Lwowie; e-mail: oleksandr@wp.pl.

${ }^{1}$ Por. G. Dagron, Ikonoklazm i ustanowienie ortodoksji (726-847), w: Historia chrześcijaństwa. Religia - kultura - polityka, t. 4: Biskupi, mnisi i cesarze 610-1054, red. J.M. Mayer - Ch.I.L. Pietri - A. Vauchez - M. Venard, red. wyd. polskiego J. Kłoczowski, Warszawa 1999, 89-91; A. Gardner, Theodore of Studium: His Life and Times, London 1905, New York 1974, 7-9.

${ }^{2}$ Por. Dagron, Ikonoklazm, s. 84-100. 
zów. Zwróciła się ona do papieża Hadriana I (772-795), by poinformować go o decyzji zwołania soboru i prosić, żeby zechciał pojednać się z patriarchą Tarazjuszem. Papież wyraził zgodę na zwołanie soboru i wysłanie legatów. Patriarchom wschodnim (Aleksandrii, Antiochii i Jerozolimy) uczestnictwo W soborze uniemożliwiła niekorzystna sytuacja związana z podbojami arabskimi. Pierwsza sesja soboru została otwarta we wrześniu 787 r. w Nicei. Na soborze stwierdzono, że Kościół uznaje święte i godne czci ikony, znak krzyża i relikwie świętych. Potępiono zebranie z Hiereia. Debaty soborowe nie miały jednak charakteru wyczerpującego omówienia teologicznego podjętej problematyki ${ }^{3}$.

W niespełna trzydzieści lat po Soborze Nicejskim II konflikt wokół obrazów wystąpił ponownie. Cesarz Leon V (813-820) w 815 r. skazał patriarchę konstantynopolitańskiego Nikefora na wygnanie, a na patriarchę wybrał Teodotosa, osobę świecką. Zwołał on sobór, który uznał ikonoklastyczny sobór w Hiereia i zatwierdził nową doktrynę. Dopiero po śmierci cesarza Teofila (829-842), cesarzowa Teodora rozpoczęła proces przywracania na nowo kultu obrazów. W 843 r. zwołano lokalny synod, na którym uznano Sobór Nicejski II z 787 r. z jego postanowieniami teologicznymi za doktrynalny punkt odniesienia dla późniejszej praktyki wiary ${ }^{4}$.

W dobie ikonoklazmu po stronie obrońców kultu obrazów pojawili się wielcy myśliciele - Nikefor (758-829), patriarcha Konstantynopola, i Teodor Studyta (759-826), opat klasztoru Studion koło Konstantynopola. Pod przywództwem Teodora mnisi wyróżniali się surowością i nieprzejednaniem wobec decyzji władz świeckich sprzeciwiających się ortodoksyjnej wierze i moralności. Oprócz negatywnego ustosunkowania się do herezji ikonoklazmu, mnisi wyrazili sprzeciw wobec powtórnego małżeństwa cesarza Konstantyna VI (780-797). W styczniu 795 r. zmusił on swoją prawowitą małżonkę Marię, by wstąpiła do klasztoru, a poślubił swoją kochankę, Teodote. Patriarcha Tarazjusz ze względu na zakładane konsekwencje nie chciał obłożyć cesarza ekskomuniką i zwlekał z usunięciem kapłana Józefa, który pobłogosławił cesarski związek małżeński. Studyci zerwali więź z Tarazjuszem, któremu zarzucili, że narusza przepisy kościelne. W ten sposób powstała tzw. schizma „moechjańska”. Po przejęciu władzy przez Irenę (797-802) Tarazjusz obłożył ekskomuniką kapłana Józefa, co było postrzegane jako rzekomy koniec schizmy. Jednak za patriarchy Nikefora Józef został przywrócony do posługi, a studyci znów zerwali jedność wiary z patriarchą ${ }^{5}$.

W kontekście powyżej zarysowanych wydarzeń jednym z głównych tematów teologicznych podejmowanych przez ortodoksyjnych pisarzy chrze-

${ }^{3}$ Por. tamże, s. 108-114; Gardner, Theodore of Studium, s. 40-45.

${ }^{4}$ Por. Dagron, Ikonoklazm, s. 123-137; Gardner, Theodore of Studium, s. 139-147.

${ }^{5}$ Por. Dagron, Ikonoklazm, s. 118-121. Na temat małżeństwa Konstantyna VI zob. Gardner, Theodore of Studium, s. 50-65, 115-129. 
ścijańskich stała się niezależność Kościoła od władzy cesarskiej, której interwencje w określenie kwestii dotyczących wiary i moralności przyczyniły się do powstania herezji i schizmy. Obrońcy ortodoksji pragnęli w swych pismach wykazać, iż dogmaty i reguły Kościoła winny pochodzić nie od cesarzy, lecz od biskupów. W tym kontekście zaczyna się kreować idea pentarchii ${ }^{6}$, jako rękojmi ortodoksyjności i jedności Kościoła powszechnego. Niniejszy artykuł, poświęcony omówieniu tej idei u św. Teodora Studyty ${ }^{7}$, został podzielony na cztery części. W pierwszej części zostaną przedstawione poglądyTeodora mówiące o tym, iż ortodoksyjna nauka jest podstawą jedności Kościoła powszechnego, w drugiej - przekonanie, że stróżem ortodoksyjności jest eklezjalny organ pentarchii. W trzeciej części zostanie omówiona pozycja patriarchy Rzymu w orbicie pentarchii, w czwartej zaś - geneza Teodorowych poglądów na temat pentarchii.

1. Ortodoksyjność wiary jako podstawa jedności Kościoła. Św. Teodor Studyta mocno podkreśla jedność całego Kościoła opartą na apostolskiej wierze ${ }^{8}$. Według niego Głową całego kościelnego Ciała jest Chrystus ${ }^{9}$, a wierni stanowią Jego Ciało ${ }^{10}$. Ze względu na to, że Kościołem zarządza pięciu patriarchów (Rzymski, Konstantynopolitański, Aleksandryjski, Antiocheński i Jerozolimski), którzy stanowią pięciogłowy urząd Kościoła ( $\tau$ ò

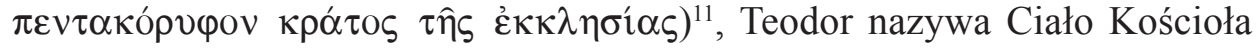
pięciogłowym $(\pi \varepsilon v \tau \alpha \kappa o ́ \rho v \varphi o v \sigma \omega \hat{\omega} \mu)^{12}$. Właśnie podkreślanie znaczenia pięciu patriarchów w zarządzaniu Kościołem (pentarchia) ukazuje, że komu-

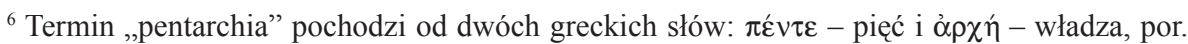
Liddell - Scott, s. 1361 , s.v. $\pi \varepsilon v \tau \alpha \rho \chi i \alpha$.

${ }^{7}$ „Pentarchiczne” poglądy św. Teodora Studyty w przeważającej mierze są obecne w epistularnej spuściźnie tego autora. W niniejszym artykule powołujemy się na listy Teodora Studyty w wydaniu G. Fatouros: Theodori Studitae Epistulae, Corpus Fontium Historiae Byzantinae, vol. 31/1 (Ep. 1-70) - vol. 31/2 (Ep. 71-564), Berlin - New York 1992.

${ }^{8}$ Por. P. O'Connell, The Ecclesiology of St Nicephorus I (758-828), Patriarch of Constantinople. Pentarchy and Primacy, Roma 1972, 221-222.

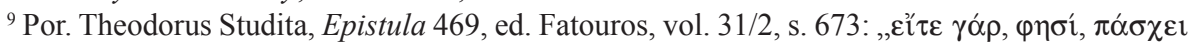

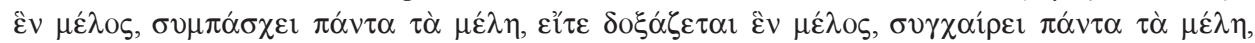

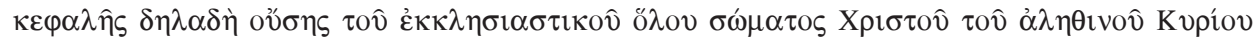

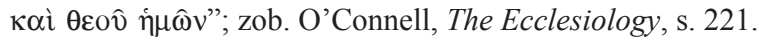

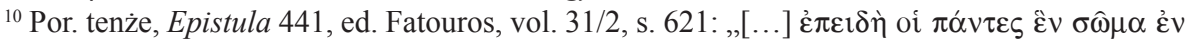

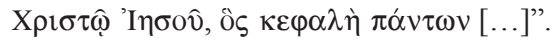

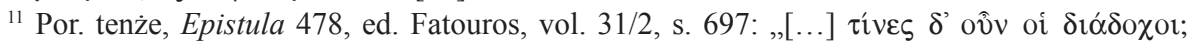

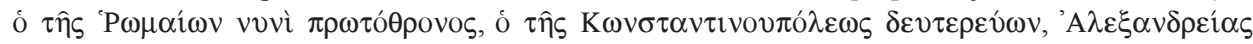

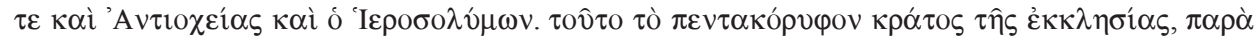

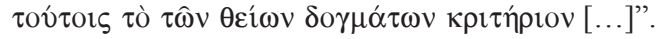

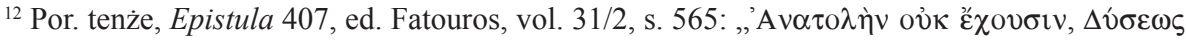

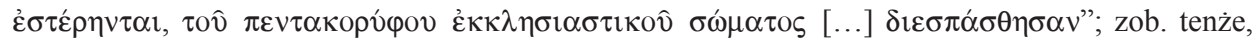
Epistula 406. 
nię Kościoła stanowią różne lokalne Kościoły, które wspólnie tworzą i wyrażają apostolski i powszechny Kościół ${ }^{13}$. Każdy patriarchat jest nieodłączną częścią Kościoła Katolickiego. O tym może świadczyć fragment, w którym Teodor pisze, że jeżeli dzieje się dobro w patriarchacie konstantynopolitańskim, to dzieje się ono również w Kościele Katolickim ${ }^{14}$. Przynależność do jednego patriarchatu oznacza przynależność do Kościoła powszechnego, a przez to do każdego innego patriarchatu. Stojący na jego czele patriarcha uosabia Chrystusa - Głowę Kościoła, a wierni stanowiąc ciało Kościoła są jednocześnie i członkami patriarchy. W liście do biskupa jerozolimskiego Teodor pisze, że wszyscy wierzący są członkami patriarchy jerozolimskiego, ponieważ wszyscy wierni stanowią Ciało Chrystusa ${ }^{15}$. W liście zaś do papieża Leona, Teodor prosi, aby był przez niego uważany nie tylko za członka jego owczarni, ale niejako za osobistą owcę papieża rzymskiego ${ }^{16}$. Między patriarchatami powinna zachodzić współpraca. Mnich studyjski pisze, że Kościół konstantynopolitański zawsze w nieszczęściach może liczyć na pomoc ze strony Kościoła rzymskiego i ubolewa, że nie doświadcza takiej pomocy od innych patriarchatów ${ }^{17}$.

Teodor Studyta przestrzega jednak, że Kościół powszechny może rozdzielić się przez herezję ${ }^{18}$. Lekceważenie dogmatów, reguł i przepisów Kościoła może doprowadzić do nieszczęścia rozłamu ${ }^{19}$. Kto odrywa się od pięciogłowego kościelnego Ciała, zostaje oderwany od wspólnoty z powszechnym Kościołem Wschodu i Zachodu ${ }^{20}$. Teodor stwierdza, że oddzielenie od Kościoła jest wielkim złem, w wyniku którego owca zostaje pozbawiona pasterza lub arcypasterza $^{21}$. Ludzie oddzieleni od Kościoła już nie tworzą Kościoła ${ }^{22}$. Jeśli nawet heretycy stanowią większość, nie świadczy to o ich ortodoksyjności, ponieważ

${ }^{13}$ Por. O'Connell, The Ecclesiology, s. 223.

${ }^{14}$ Por. Theodorus Studita, Epistula 31.

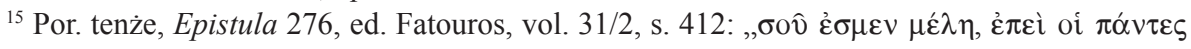

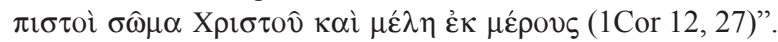

${ }^{16}$ Por. tenże, Epistula 33.

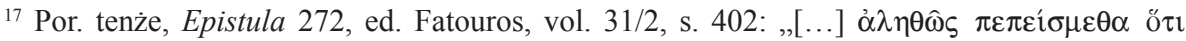

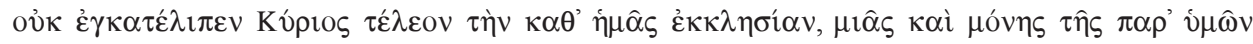

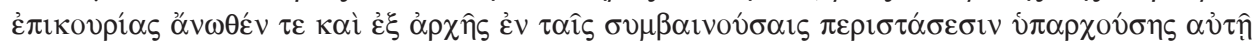
$\theta \varepsilon \circ \hat{v} \pi \rho \circ \mu \eta \theta \varepsilon i \alpha^{\prime \prime}$.

${ }^{18}$ Por. tenże, Epistula 446.

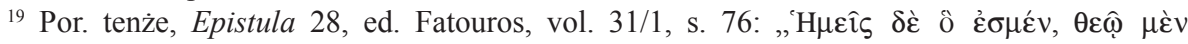

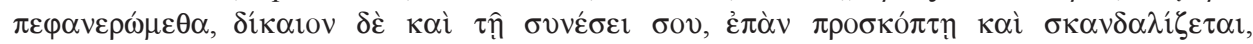

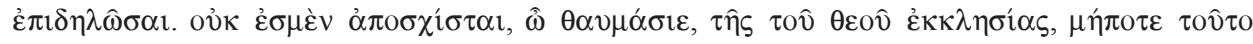

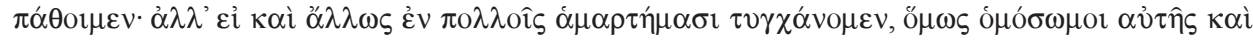

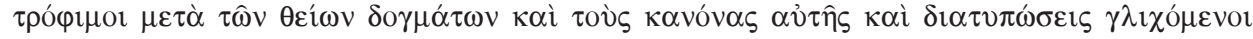
$\varphi \nu \lambda \alpha ́ \tau \tau \varepsilon \sigma \theta \alpha \iota "$

${ }^{20}$ Por. tenże, Epistula 407; zob. O'Connell, The Ecclesiology, s. 222.

${ }^{21}$ Por. tenże, Epistula 25.

${ }^{22}$ Por. tenże, Epistula 43. 
Kościół mogą tworzyć nawet trzy osoby, które wyznają ortodoksyjną wiarę ${ }^{23}$. Teodor ubolewa, że Kościół konstantynopolitański pogrążył się w głębi herezji ${ }^{24}$, upadł przez niegodziwość ${ }^{25}$, ponieważ wykazał niewierność wobec nauki VII soboru powszechnego ${ }^{26}$. W ten sposób został heretycką częścią, oddzieloną od reszty patriarchatów i oderwaną od pięciogłowego Ciała Kościoła ${ }^{27}$.

Z kwestią zachowania czystości wiary u Teodora Studyty wiąże się kwestia zachowania moralności, która polega na prowadzeniu życia zgodnego z wia$\mathrm{rac}^{28}$. Ten temat św. Teodor omawia szczególnie w kontekście ślubu udzielonego cesarzowi Konstantynowi VI. Mnich studyjski pisze, że na chrześcijaństwo składają się wiara i dobre uczynki. Jeżeli brakuje którejś ze wspomnianych postaw, to i druga nie przynosi korzyści ${ }^{29}$. Człowiek, który stwierdza, że zachowuje wiarę ortodoksyjna, ale nie kieruje się Boskimi regułami, jest tylko na pół ortodoksyjny ${ }^{30}$. Obydwie postawy - wiara i zgodne z nią postępowanie wzajemnie się dopełniają. O tym może świadczyć fragment, w którym Teodor stwierdza, że w celu zachowania prawdziwej wiary należy kierować się w życiu Boskimi regułami (kanonami) ${ }^{31}$. Teodor traktuje reguły określone przez sobory i Ojców jako równoznaczne z Ewangelią Chrystusową. Są one opieczętowane przez Ducha Świętego i określają wszystko, co dotyczy ludzkiego zbawienia $^{32}$. Z analizy niektórych tekstów wynika, że według Teodora przez

${ }^{23}$ Por. tenże, Epistula 39.

${ }^{24}$ Por. tenże, Epistula 33.

${ }^{25}$ Por. tenże, Epistulae 426 i 419.

${ }^{26}$ Por. tenże, Epistula 532.

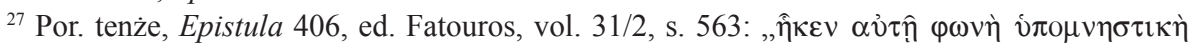

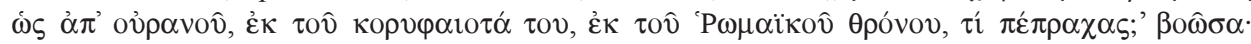

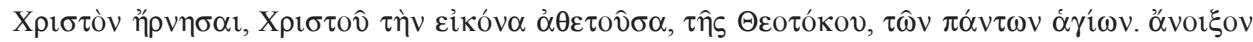

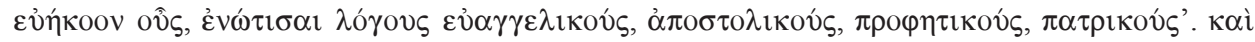

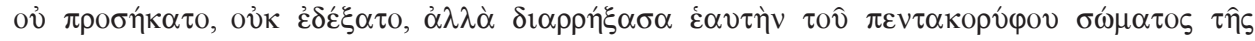

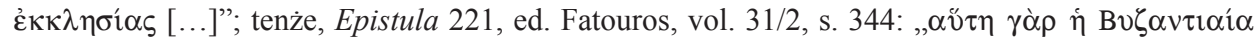

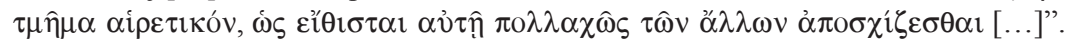

${ }^{28}$ Por. Gardner, Theodore of Studium, s. 124.

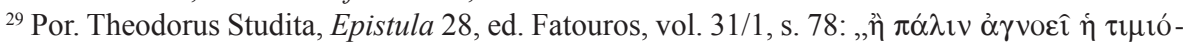

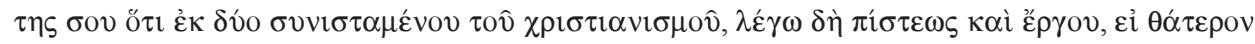

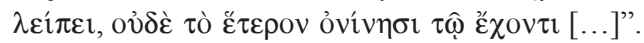

${ }^{30}$ Por. tenże, Epistula 25.

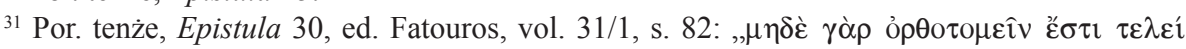

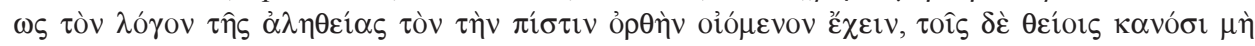
$\alpha \pi \varepsilon v \theta v v o ́ \mu \varepsilon v o v "$.

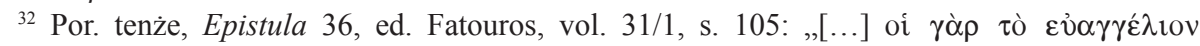

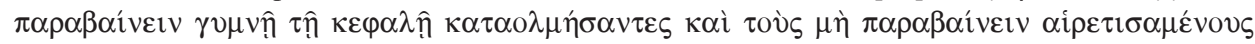

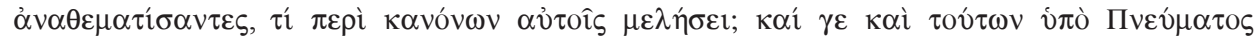

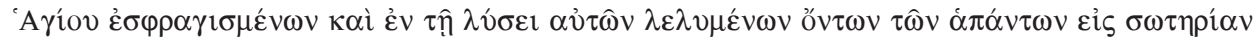

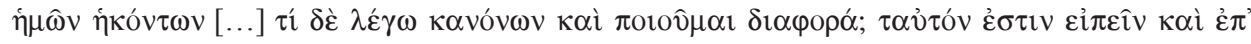

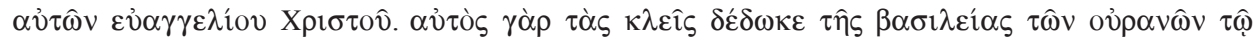

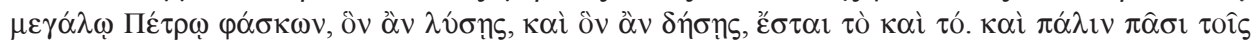


reguły, określone przez Ojców, przemawia sam Chrystus ${ }^{33}$. Teodor powołuje się na przykład Bazylego Wielkiego i podobnych do niego świętych, którzy przyjmowali reguły jako apostolskie i nie zmieniali ich, a tylko dopełniali, jeśli było to konieczne ${ }^{34}$. Człowiekowi nie wolno ani nic dodawać do tych reguł, ani niczego ujmować z nich, nawet gdyby był on władcą świeckim ${ }^{35}$. Naruszenie reguł jest naruszeniem samej Ewangelii ${ }^{36}$. Dlatego Kościół nie aprobuje działań sprzeciwiających się regułom, tak samo i zakazanych umów z ludźmi tworzącymi te działania ${ }^{37}$. Dlatego właśnie powstała schizma „moechjańska”.

Teodor podkreśla, że czystość wiary jest zachowana tylko w Kościele powszechnym, który nie akceptuje nieczystych dogmatów i postepowania sprzeciwiającego się kanonom. Kościół nie ma żadnej wady (Ef 5, 27) zarówno w aspekcie dotyczącym przedmiotu wiary, jak i w aspekcie dotyczącym określonych reguł (kanonów) ${ }^{38}$. Chociaż w ciagu wieków do Kościoła wdzierały się liczne herezje, powstawały niegodziwe dzieła, sprzeciwiające się przepisom i zakazane Konstytucjami, to jednak Kościół pozostał nienaruszony i nieskazitelny ${ }^{39}$.

2. Pentarchia jako eklezjalny organ stojący na straży ortodoksyjności wiary. Teodor Studyta naucza, że ortodoksyjność wiary opiera się na dwóch fundamentach - Piśmie świętym oraz Tradycji przekazanej Kościołowi Bożemu przez świętych Ojców (

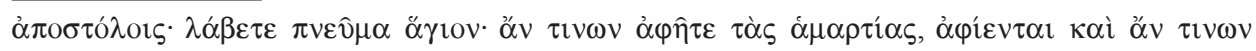

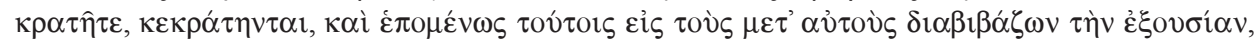

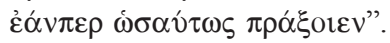

${ }^{33}$ Por. tenże, Epistula 27.

${ }^{34}$ Por. tenże, Epistula 36.

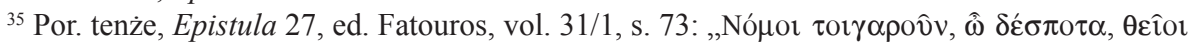

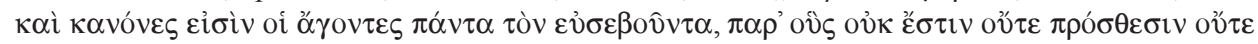

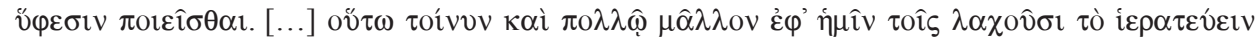

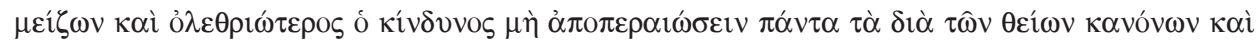

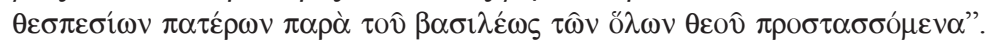

${ }^{36}$ Por. tenże, Epistula 36.

${ }^{37}$ Por. tenże, Epistula 28.

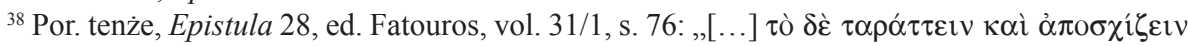

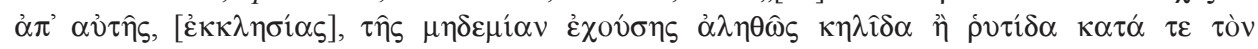

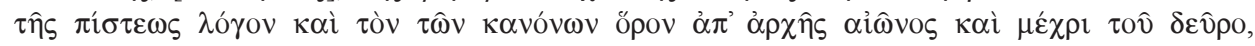

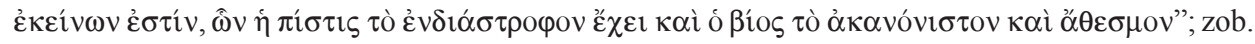

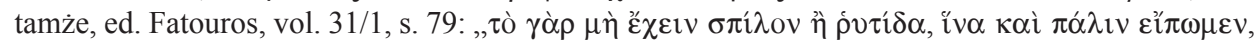

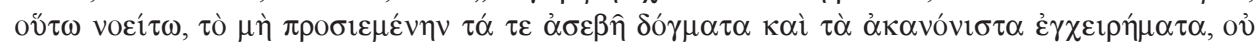

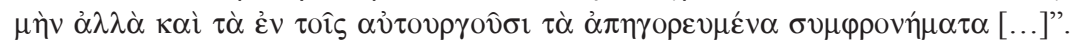

${ }^{39}$ Por. tenże, Epistula 28.

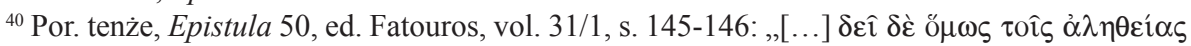

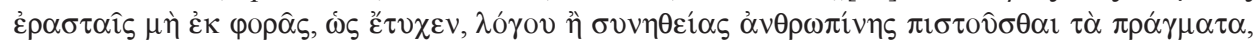

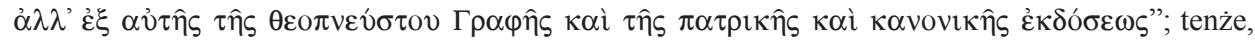

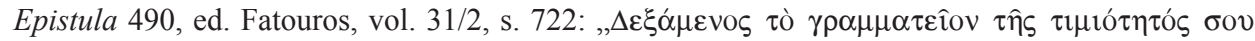

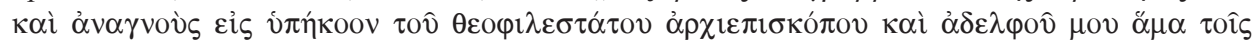


Analizując teksty, w których św. Teodor wypowiada się na temat ortodoksyjności wiary w kontekście kultu ikony, można wyodrębnić najważniejsze kryteria, które tworzą Tradycję i określają czystość wiary: zgodność z dawną historią, zgodność z wypowiedziami świętych i zgodność z nauczaniem soborowym ${ }^{41}$. W Antyrretyku Teodor szczególnie zwraca uwagę na nauczanie Ojców jako na kryterium ortodoksyjności wiary ${ }^{42}$, które przeszło od Chrystusa do dnia dzisiejszego ${ }^{43}$. Mnich studyjski akcentuje także znaczenie starożytnej praktyki - to kryterium jest wystarczające, nawet jeśli nie znajduje bezpośredniego potwierdzenia w nauczaniu Ojców czy w soborowych regułach wiary ${ }^{44}$. Jednak w kontekście ikonoklazmu i schizmy „moechjańskiej” Teodor zdaje się najbardziej podkreślać znaczenie soboru powszechnego. Naucza on, że człowiek, który odrzuca wszelką herezję i przyjmuje kanoniczne przepisy określone przez powszechne oraz lokalne sobory, jest ortodoksyjnym dzieckiem Kościoła Katolickiego ${ }^{45}$. Teodor uznaje siedem świętych soborów powszechnych ${ }^{46}$.

Sobór powszechny jest według studyjskiego mnicha źródłem jedności i doktryny w Kościele. Taki sobór powinien zostać uznany przez pięciu pa-

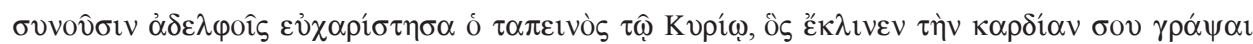

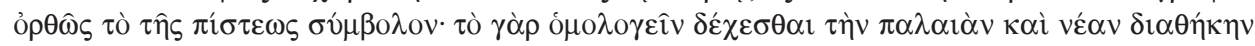

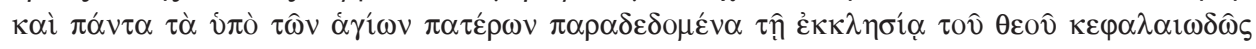

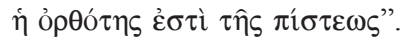

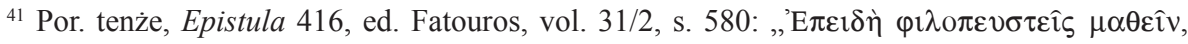

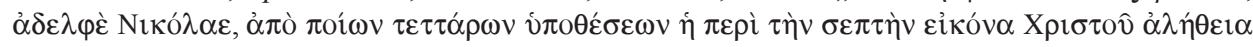

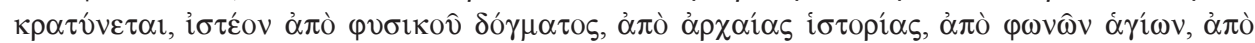

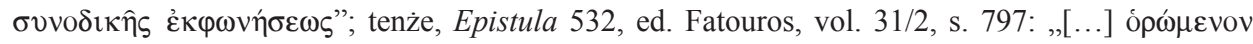

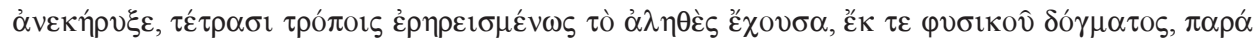

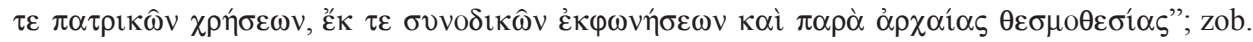
Gardner, Theodore of Studium, s. 148-150.

${ }^{42}$ Por. tenże, Antirrheticus 2, PG 99, 388; tamże 3, PG 99, 360.

${ }^{43}$ Por. tenże, Refutatio et subversio impiorum poematum, PG 99, 476A.

${ }^{44}$ Por. tenże, Antirrheticus 2, PG 99, 388.

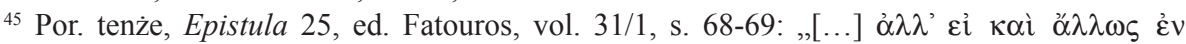

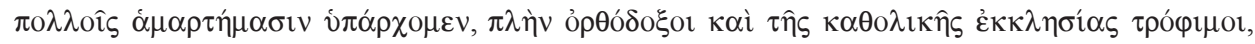

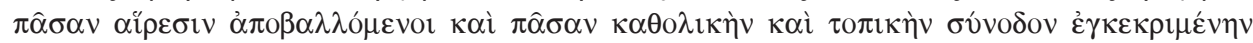

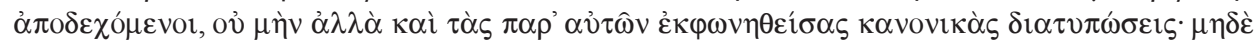

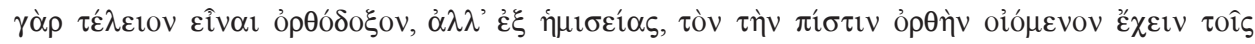

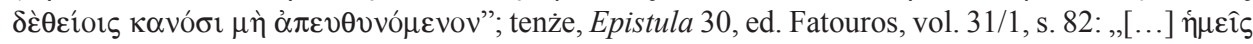

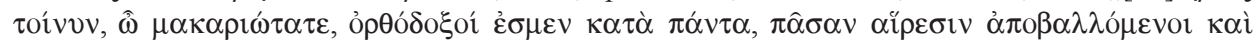

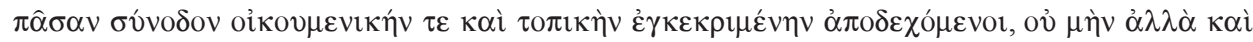

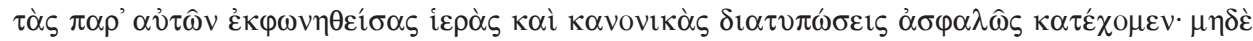

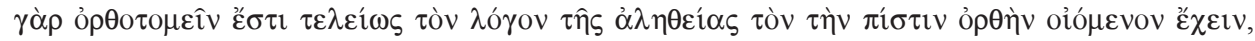

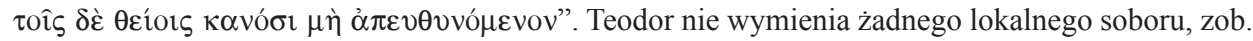
O'Connell, The Ecclesiology, s. 203.

${ }^{46}$ Por. Theodorus Studita, Epistula 490; tenże, Epistula 532; zob. O'Connell, The Ecclesiology, s. 204-205. 
triarchów, którzy z pomocą Ducha Świętego rozstrzygają, co stanowi prawdziwą doktrynę Kościoła ${ }^{47}$. Teodor stwierdza, że rozstrzyganie o Boskich i niebiańskich dogmatach zostało powierzone tylko tym, do których przemówił sam Bóg Słowo: „Co zwiążesz na ziemi, zostanie związane na niebie” (Mt 16, 19). Słowa te według Teodora dotyczą apostołów i ich następców, do których zalicza pięciu patriarchów, mających prawo rozstrzygać o Boskich dogma$\operatorname{tach}^{48}$. Każdy z pięciu patriarchów powinien odznaczać się jednomyślnością, aby dojść do wspólnego porozumienia ${ }^{49}$. Wszyscy razem mają najwyższy osąd w Kościele i ich zgoda jest konieczna do uznania soboru powszechnego. W kontekście obrazoburczych zebrań w Konstantynopolu Teodor pisze, że Kościół konstantynopolitański nie może zwołać soboru bez zgody pięciu patriarchów, a przede wszystkim rzymskiego ${ }^{50}$. Powołując się na historyczne doświadczenie Kościoła, Studyta stwierdza, że VI sobór powszechny został zaakceptowany przez pięciu patriarchów, a tzw. sobór w Blachernach został potępiony przez czterech patriarchów, za wyjątkiem konstantynopolitańskiego. Tak samo Sobór Nicejski II został zaakceptowany przez pięciu patriarchów $^{51}$. Potwierdzenie dekretów soborowych przez patriarchów wyraża jednomyślność apostolskiego i powszechnego Kościoła ${ }^{52}$.

Jeżeli chodzi o rolę władców świeckich w określaniu doktryny kościelnej, to według niego posiadają oni władzę i odpowiednie środki jedynie po to, by potwierdzić wszystko, co zostało rozstrzygnięte przez władzę kościel$n_{a}{ }^{53}$. Teodor zwraca uwagę, że właśnie z tego powodu, iż cesarze Konstantyn

${ }^{47}$ Por. O'Connell, The Ecclesiology, s. 226-227.

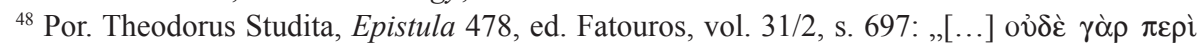

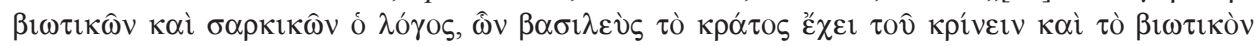

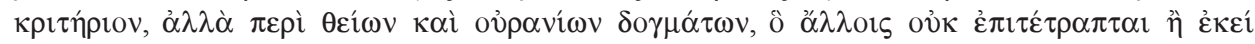

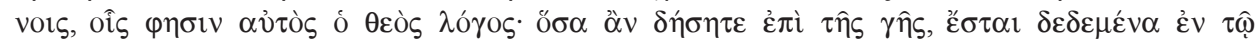

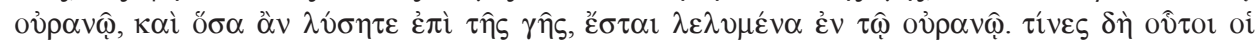

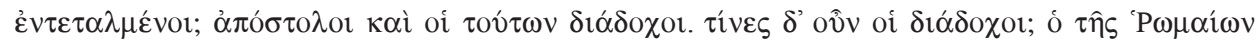

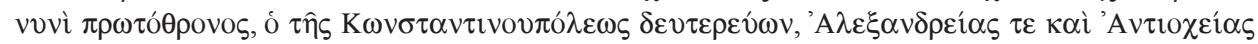

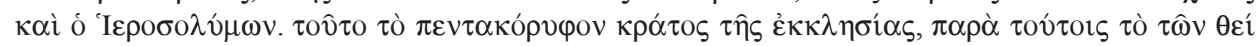

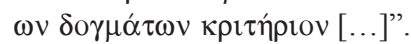

${ }^{49}$ Por. tenże, Epistula 53.

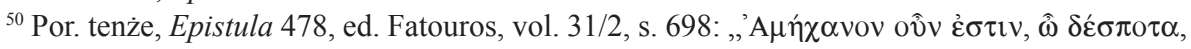

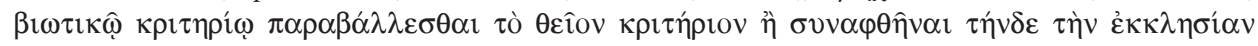

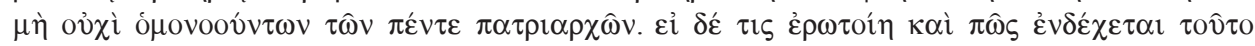

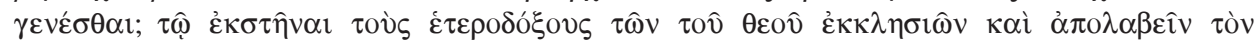

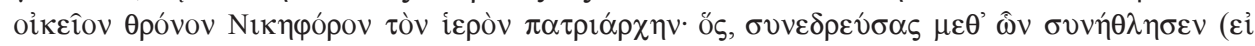

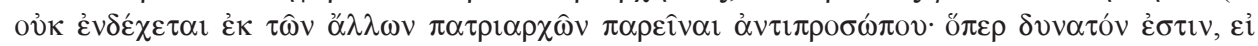

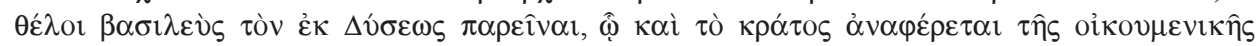

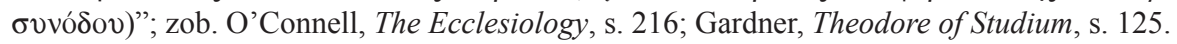

${ }^{51}$ Por. Theodorus Studita, Epistula 416.

${ }^{52}$ Por. O'Connell, The Ecclesiology, s. 223-224.

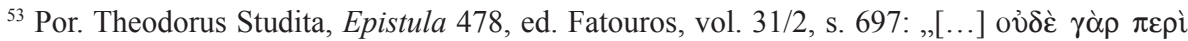

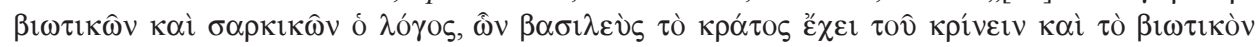


i Leon rozstrzygali kwestie wiary dotyczące kultu ikony, Kościół konstantynopolitański został oddzielony od czterech pozostałych Kościołów ${ }^{54}$.

3. Pozycja patriarchy Rzymu w orbicie pentarchii. W nauczaniu Teodora Studyty w orbicie pentarchii uprzywilejowane stanowisko zajmuje patriarcha rzymski ${ }^{55}$. Teodor wyjaśnia, że Chrystus ogłosił Piotra zwierzchnikiem wszystkich apostołów ${ }^{56}$. Godność pierwszeństwa przechodzi na następców Piotra $^{57}$, dlatego papież rzymski jest apostolską Głową Kościoła Chrystuso-

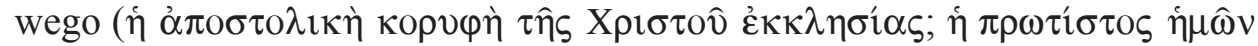

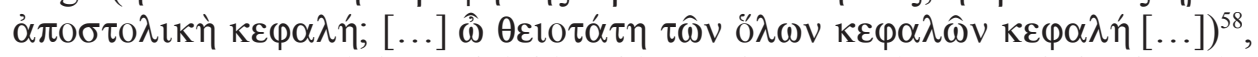

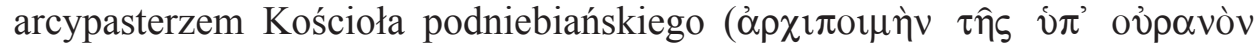

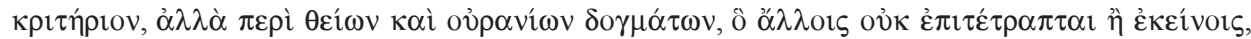

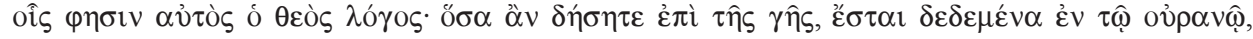

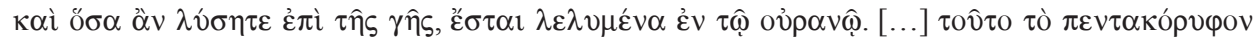

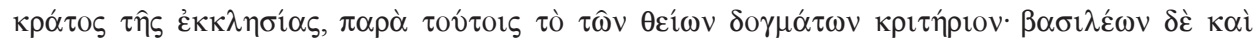

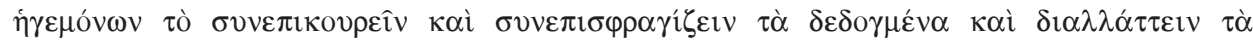

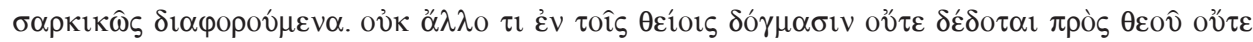

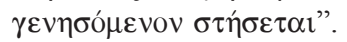

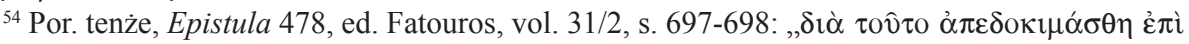

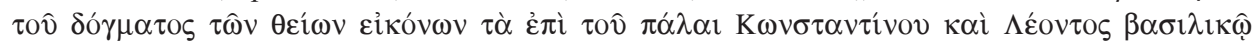

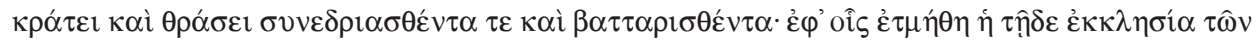

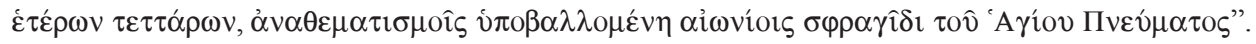

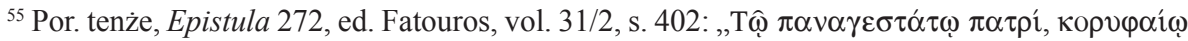

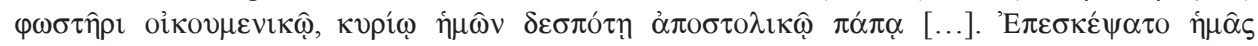

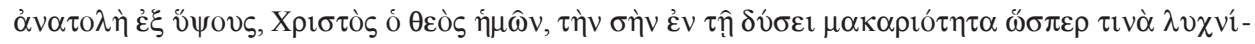

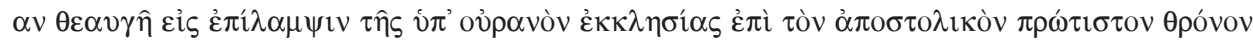

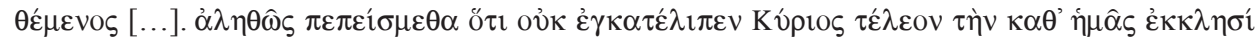

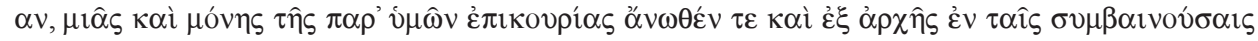

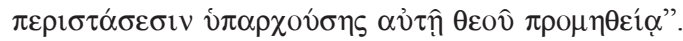

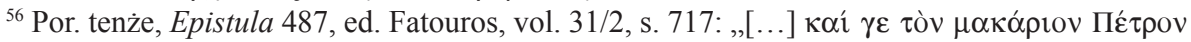

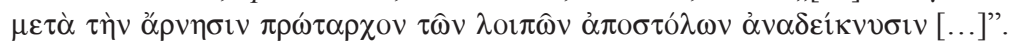

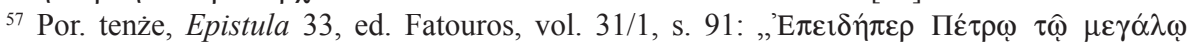

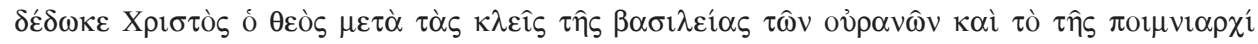

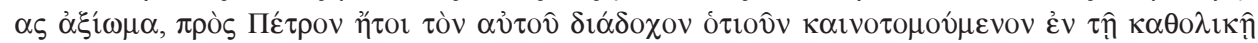

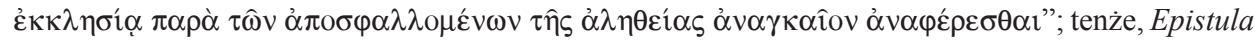

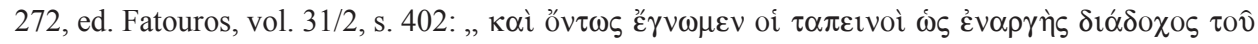

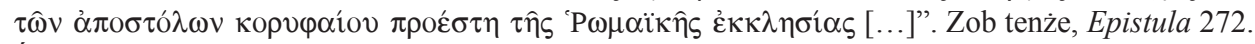
Świadomość moralnej jedności Piotra i jego następców na Stolicy Rzymskiej jest tak wielka, że Teodor w swoich tekstach nie rozróżnia Piotra i jego następców, por. O’Connell, The Ecclesiology, s. 206-211.

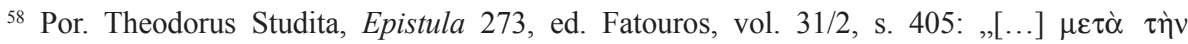

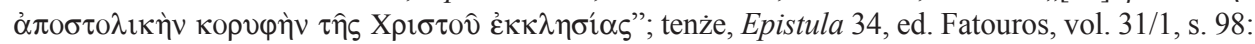

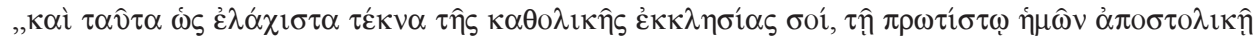

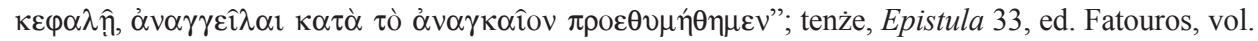

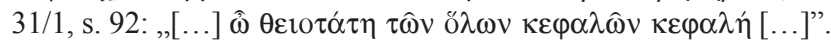


$\dot{\varepsilon} \kappa \kappa \lambda \eta \sigma i \alpha \varsigma)^{59}$. Otrzymał on klucz do Ewangelii od Chrystusa przez Piotra oraz jego następców, włącznie $z$ bezpośrednim swoim poprzednikiem ${ }^{60}$. Teodor nazywa papieża pierwszym arcykapłanem; wywyższonym przez Boga pasterzem owiec Chrystusowych, który posiada klucze Królestwa niebiańskiego; kamieniem wiary, na którym zbudowano Kościół katolicki; Piotrem, który upiększa Stolicę Piotrową i rządzi na niej; pierwszym spośród wszystkich ${ }^{61}$; powszechnym światłem ${ }^{62}$; równym aniołom, błogosławionym i apostolskim ojcem $^{63}$, świętą i błogosławioną głową ${ }^{64}$, boskim pierwszym pasterzem ${ }^{65}$.

Ze względu na to, że biskup Rzymu zajmuje uprzywilejowane stanowisko w Kościele powszechnym, Kościół rzymski jest pierwszym spośród Kościołów Bożych ${ }^{66}$. Rzym jest pierwszym ze wszystkich miast ${ }^{67}$. W Rzymie znajduje się święty apostolski ołtarz ${ }^{68}$, najwyższy apostolski ołtarz ${ }^{69}$, pierwszy apostolski ołtarz ${ }^{70}$, ołtarz zwierzchnika, na którym Chrystus położył klucze wiary,

${ }^{59}$ Por. tenże, Epistula 33, ed. Fatouros, vol. 31/1, s. 93.

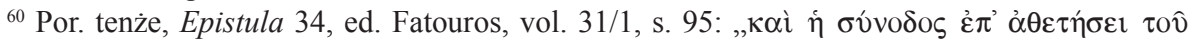

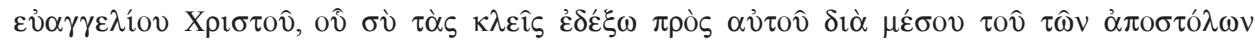

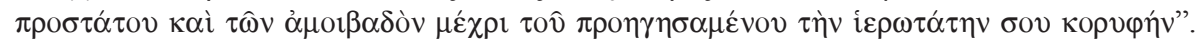

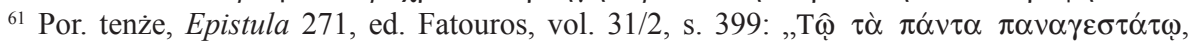

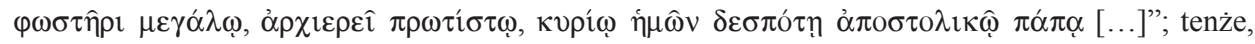

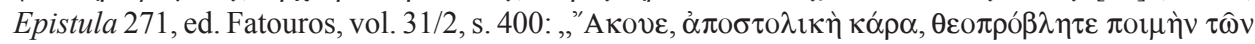

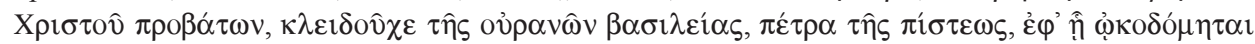

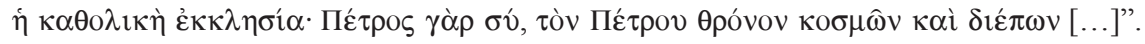

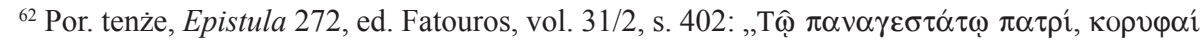

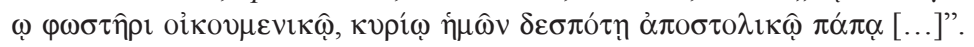

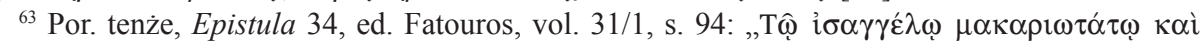

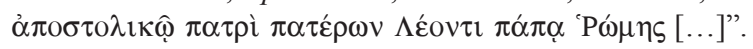

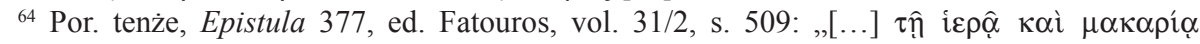

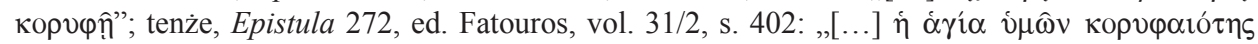

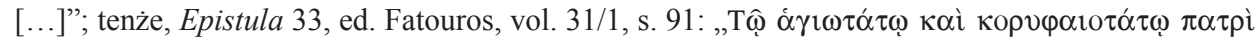

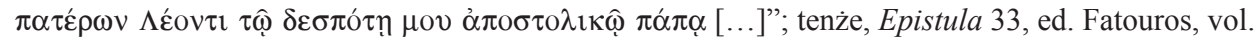

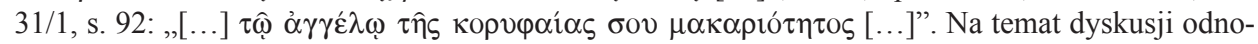
śnie epistolarnej tytulatury por. O'Connell, The Ecclesiology, s. 215-217.

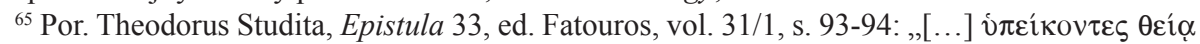
$\pi о \mu \varepsilon v \alpha \rho \chi i \alpha \underline{\alpha}[\ldots] "$.

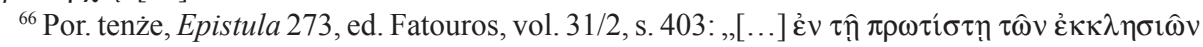

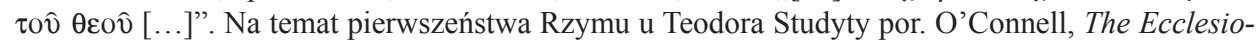
$\log y$, s. 211-220.

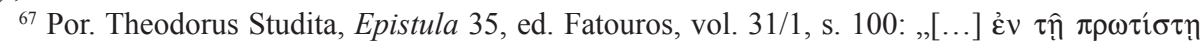
$\tau \hat{\omega} \nu \pi \lambda^{\prime} \varepsilon \omega \nu[\ldots] ”$.

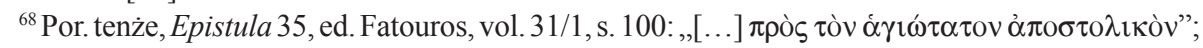
zob. tenże, Epistula 35; 377.

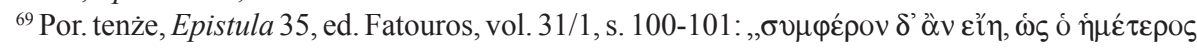

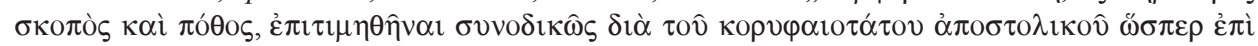

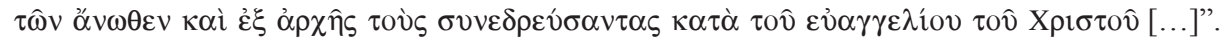

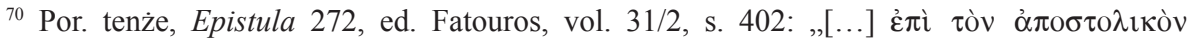
$\pi \rho \omega ́ \tau \imath \sigma \tau o v ~ \theta \rho o ́ v o v[\ldots] "$. 
których nie pokonają bramy piekielne, czyli usta heretyków ${ }^{71}$. Rzym ma za zadanie troszczyć się o wszystkie Kościoły ${ }^{72}$.

Kościół rzymski jest arbitrem w sprawach wiary ${ }^{73}$. Papież, według Teodora, jest od początku niezanieczyszczonym źródłem ortodoksyjności ( $\dot{\eta} \alpha \dot{\alpha} \theta 0 ́ \lambda \omega \tau$ ○

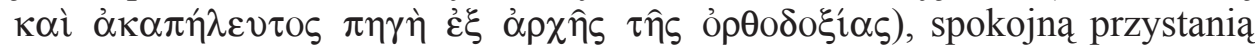
całego Kościoła, oddaloną od wszelkich heretyckich burz ${ }^{74}$. Postanowienia papieskie są formułowane pod natchnieniem Ducha Świętego ${ }^{75}$. Dla wspólnej korzyści trzeba przyjać od dawnego Rzymu wyjaśnienia w sprawach wiary zgodnie z dawną Tradycją Ojców. W Rzymie znajduje się naczelny Kościół Boży, na stolicy którego zasiadał Piotr, któremu Pan powiedział: „Ty jesteś Piotr, i na tej opoce zbuduję Kościół mój, a bramy piekielne nie przemogą go" $(\mathrm{Mt} 16,18)^{76}$. Zgodnie z przyjętym od dawna zwyczajem bez zgody papieża nie może odbyć się żaden ortodoksyjny sobór ${ }^{77}$. Zachowując dawny zwyczaj

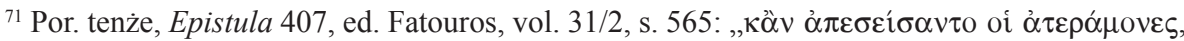

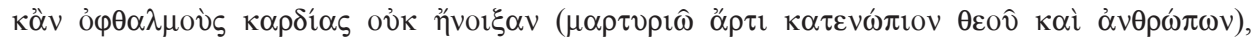

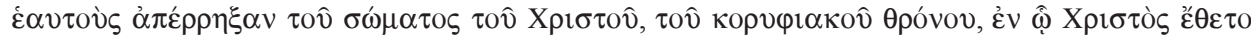

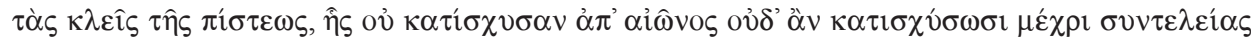

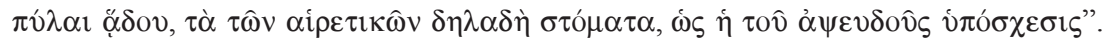

${ }^{72}$ Por. O'Connell, The Ecclesiology, s. 215.

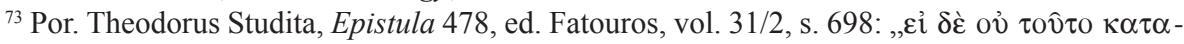

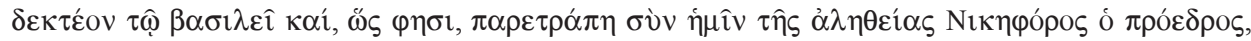

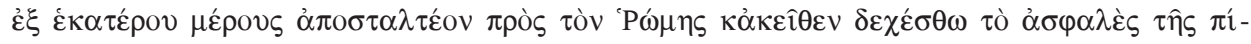

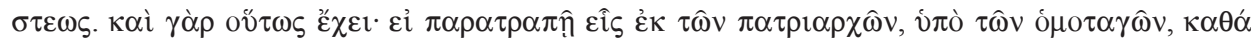

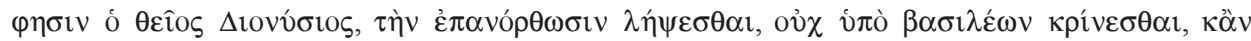

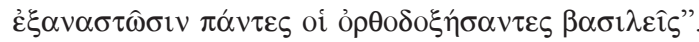

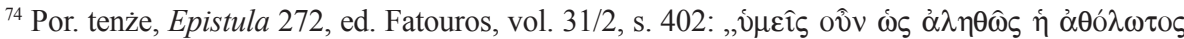

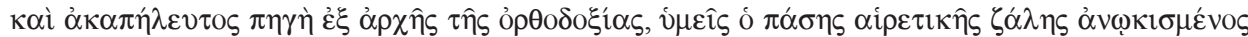

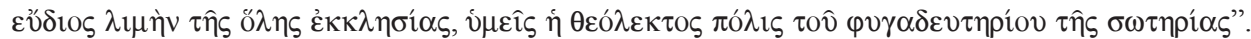

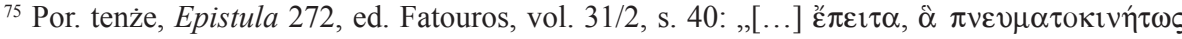

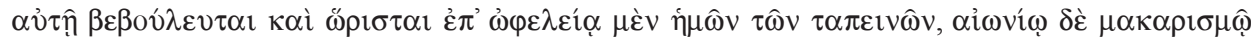

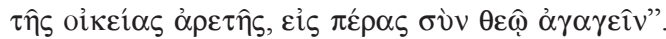

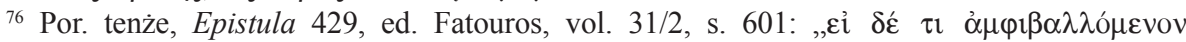

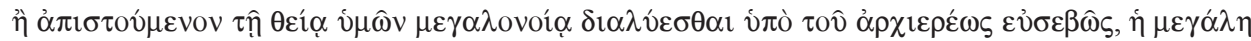

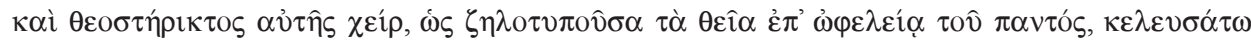

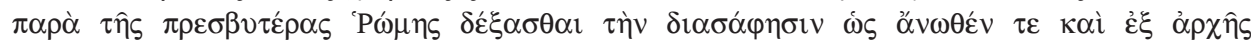

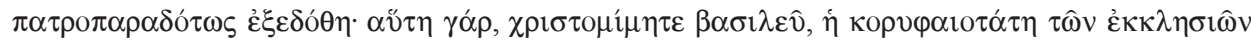

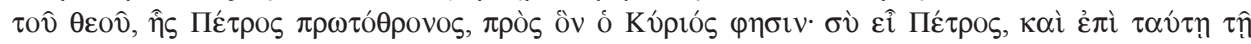

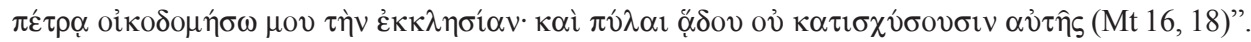

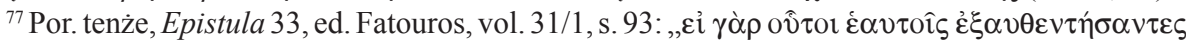

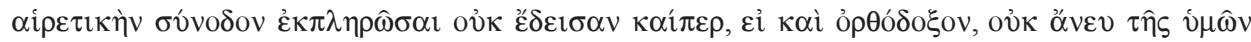

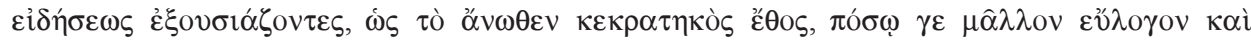

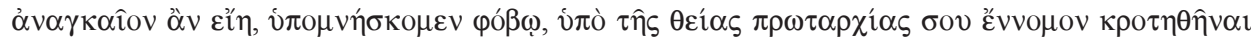

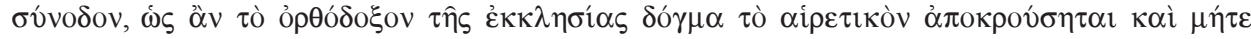

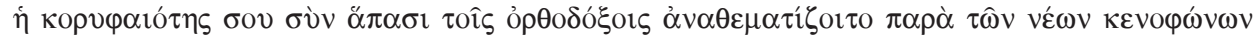

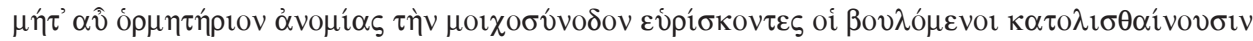

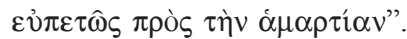


Ojców, biskupa Rzymu należy zawiadomić o wszystkich nowościach w Kościele Katolickim wprowadzonych przez tych, którzy odstępują od wiary. Teodor prosi papieża Leona, aby podobnie jak jego poprzednik Leon Wielki, zajął odpowiednie stanowisko w sprawie herezji ikonoklazmu. Dąży do tego, by Rzym podjął inicjatywę zwołania soboru powszechnego w sprawie kultu obrazów $^{78}$. Także w związku ze sprawą ślubu udzielonego cesarzowi Konstantynowi VI dąży do tego, by najwyższa Apostolska Stolica na soborze potępiła tych, którzy sprzeciwiają się Ewangelii Chrystusowej ${ }^{79}$. Należy zaznaczyć, że Teodor wspomina o soborze tylko w liście do patriarchy Rzymskiego. W listach do innych patriarchów nie porusza kwestii zwołania soboru ${ }^{80}$.

Kościół rzymski jest punktem odniesienia, centrum jedności Kościoła ${ }^{81}$. Za pośrednictwem listów synodalnych kierowanych do Rzymu dokonuje się akt jedności ${ }^{82}$. Nawet heretycy starają się znaleźć poparcie Rzymu dla swoich idei ${ }^{83}$. Według Teodora zerwanie łączności z Rzymem oznacza zerwanie łączności z całym Kościołem. Jeżeli bowiem konstantynopolitańscy heretycy oddzielili się od zwierzchniego patriarchatu, czyli rzymskiego, to oderwali się także od trzech pozostałych patriarchatów, a w konsekwencji i od Chrystusa, ich Głowy ${ }^{84}$.

Należy zwrócić uwagę, że oprócz wyżej omówionych tekstów istnieje również wypowiedź, w której Teodor dość chłodno wypowiada się o biskupie Rzymu. Pisze, że nie obchodzi go jak postępuje papież. Gdy papież powiedział, że nie martwi się z powodu jawnych grzechów kapłana, to nie ośmieszył jakiegokolwiek kapłana, lecz samą Głowę Kościoła ${ }^{85}$. Wypowiedź ta jest bar-

\footnotetext{
${ }^{78}$ Por. tenże, Epistula 33; zob. Dagron, Ikonoklazm, s. 135.

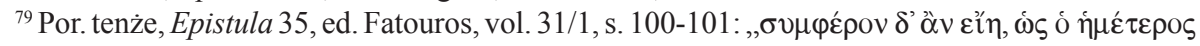

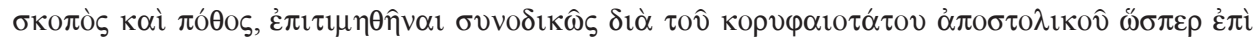

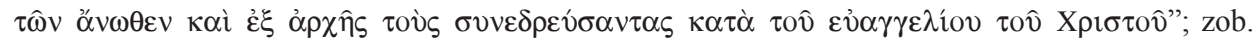
Gardner, Theodore of Studium, s. 125-127.

${ }^{80}$ Por. O'Connell, The Ecclesiology, s. 224.

${ }^{81}$ Por. tamże, s. 214.

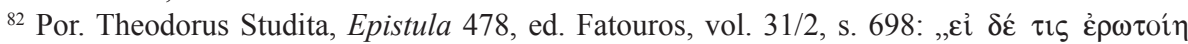

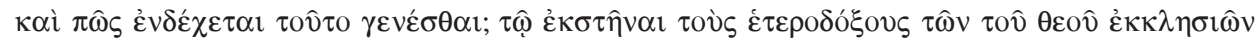

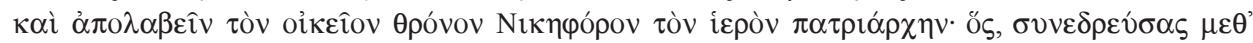

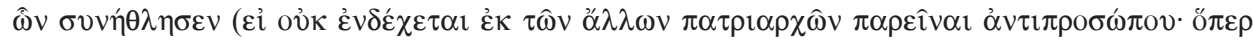

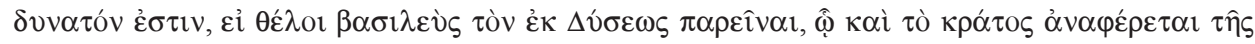

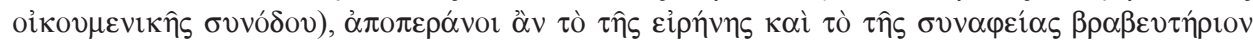

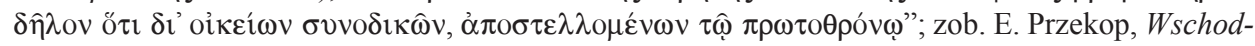
nie patriarchaty starożytne (IV-X $w$.), Warszawa 1984, 110-116.

${ }^{83}$ Por. Theodorus Studita, Epistula 38.

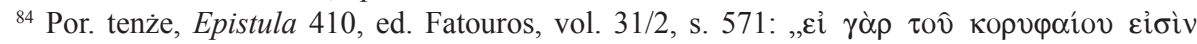

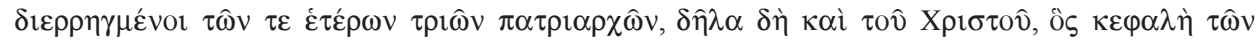

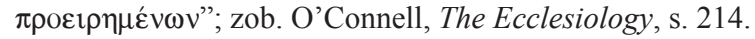

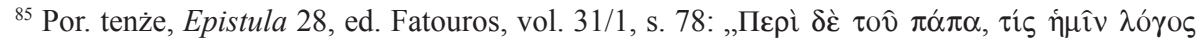

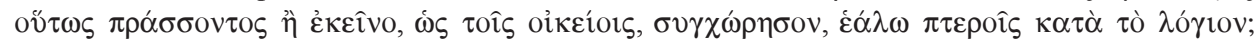


dzo trudna do wytłumaczenia. Chodzi w niej o kapłana Józefa, który udzielił ślubu Konstantynowi VI. Jednak ten niejasny tekst w żadnym wypadku nie może być kluczem do Teodorowego rozumienia pozycji biskupa Rzymu ${ }^{86}$.

Trzeba pamiętać, że św. Teodor Studyta rozpatruje pierwszeństwo biskupa Rzymu nie w izolacji od innych patriarchatów, lecz w orbicie całego Kościoła $^{87}$. Według Teodora wszystkie stolice patriarchalne mają taką samą godność jak stolica rzymska i są zakorzenione w pełnej tradycji apostolskiej ${ }^{88}$. Jeżeli jeden patriarcha zbłądzi w kwestii wiary, to powinien zostać upomniany przez równego mu, nie tylko przez patriarchę rzymskiego ${ }^{89}$. Każdy patriarcha jest kościelnym zwierzchnikiem w granicach powierzonych jego pasterskiej opiece. O tym może świadczyć fragment, z którego wynika, że w granicach patriarchatu konstantynopolitańskiego lokalny patriarcha jest Boską i zwierzchnią Głową ${ }^{90}$. Mnich studyjski oddaje należny szacunek każdemu patriarsze. Konstantynopolitańskiego patriarchę Nikefora nazywa Świętą Głową ${ }^{91}$, boskim i naczelnym Szczytem wszystkich Głów ${ }^{92}$. Papieża aleksandryjskiego nazywa wszechświętym Ojcem ojców, Światłem światła, pierwszym spośród wiernych, apostolskim Zwierzchnikiem ${ }^{93}$. Podobnie wypowiada się $\mathrm{w}$ liście do patriarchy jerozolimskiego ${ }^{94}$. Tego ostatniego darzy szczególną czcią. Pisze, że chociaż patriarcha jerozolimski w porządku pa-

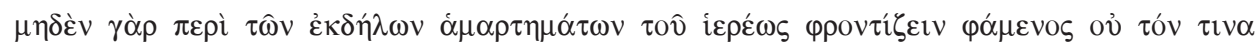

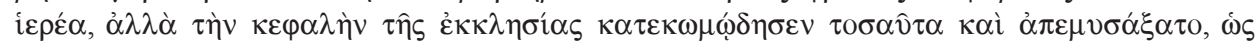

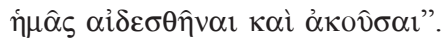

${ }^{86}$ Por. O'Connell, The Ecclesiology, s. 215-219.

${ }^{87}$ Por. tamże, s. 217.

${ }^{88}$ Por. Theodorus Studita, Epistula 469.

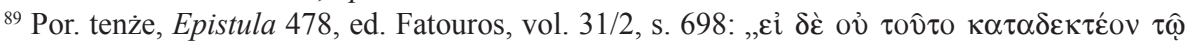

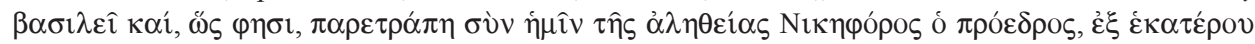

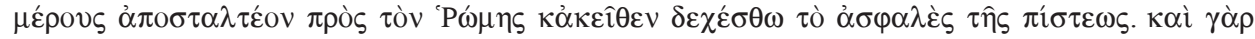

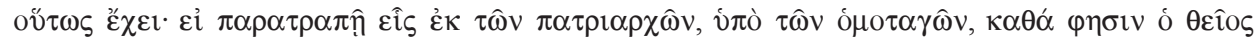

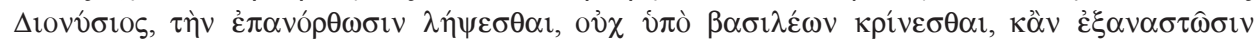

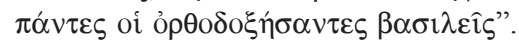

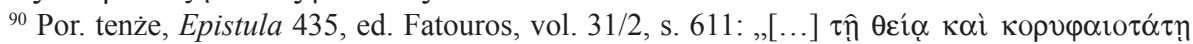
$\kappa \alpha ́ \rho \alpha[\ldots] "$.

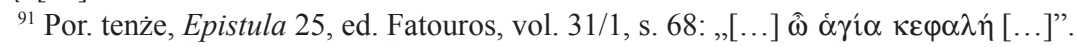

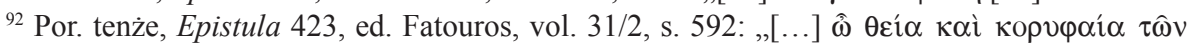

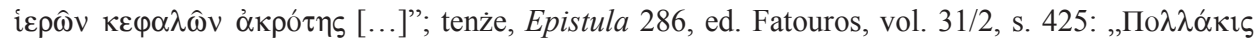

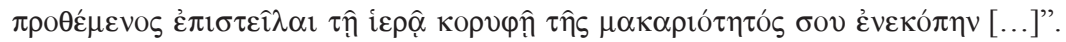

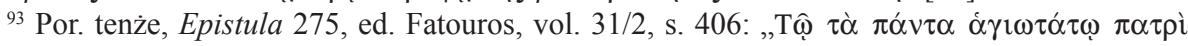

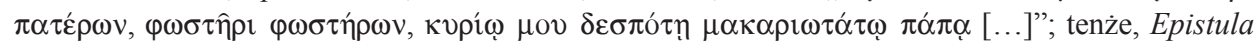

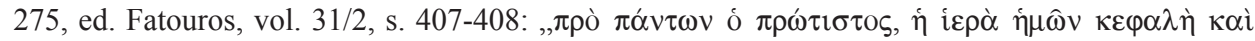

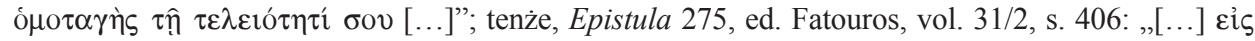

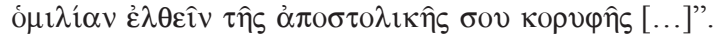

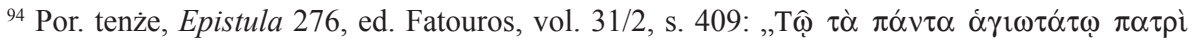

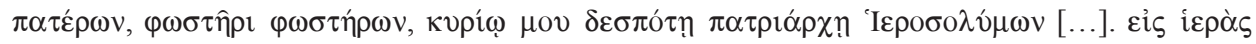

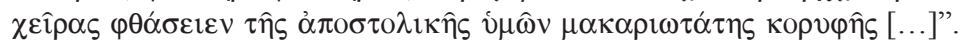


triarchatów zajmuje piąte miejsce, to jednak jest pierwszym spośród patriarchów, ponieważ jest zwierzchnikiem wielu ważnych świątyń znajdujących się pod jego juryzdykcją ${ }^{95}$. Najwyższa godność znajduje się tam, gdzie urodził się Chrystus, Biskup dusz i Arcykapłan wszystkich, i gdzie spełnił wszystkie swoje Boskie dzieła ${ }^{96}$.

Chociaż według Teodora w biskupie Rzymu Kościół znajduje gwarancję doktryny wiary oraz jedności, i z nim cały Kościół musi się zgadzać, to jednak tylko w momencie szczególnego kryzysu, kiedy jest niemożliwe tradycyjne rozwiązanie sporu, biskup Rzymu odgrywa swoją szczególną rolę w odnowieniu jedności Kościoła w apostolskiej wierze ${ }^{97}$.

4. Geneza pentarchicznych poglądów Teodora Studyty. Przekonanie na temat soborowego definiowania Credo, które stanowi podstawę jedności Kościoła, Teodor Studyta czerpie z historycznego doświadczenia Kościoła. W Kościele starożytnym sobór był wyrazem jedności i jednomyślności. Chrześcijaństwo starożytne w rzeczywistości było jednością w różnorodności, rodziną utwierdzoną na zasadzie równych sióstr-Kościołów. Jedność polegała na „soborowości”, na wspólnym określeniu wiary i życia sakramentalnego ${ }^{98}$. Wszyscy starożytni patriarchowie musieli potwierdzić soborowe dekrety ${ }^{99}$. Generalnie w starożytnym chrześcijaństwie nie kwestionowano wiary zdefiniowanej przez sobór powszechny. Dekrety soborowe przyjmowano z wiara, podobnie jak nauczanie Pisma Świętego ${ }^{100}$.

W starożytnym Kościele pierwszeństwo należało do Rzymu, ponieważ był on stolicą władzy rzymskiej, miejscem spoczynku św. Piotra i Pawła oraz bastionem ortodoksyjnego nauczania przez setki lat ${ }^{101}$. Żaden sobór nie był uznawany za ekumeniczny, jeżeli nie został potwierdzony lub przynajmniej uznany przez następcę św. Piotra ${ }^{102}$.

Teoretyczne początki eklezjalnej odrębności stolic patriarszych sięgają pierwszego soboru powszechnego w Nicei (325). Sobór podkreśla powszech-

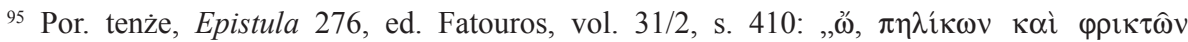

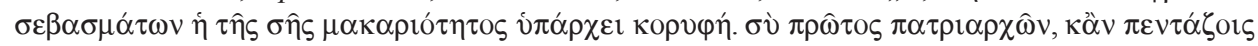

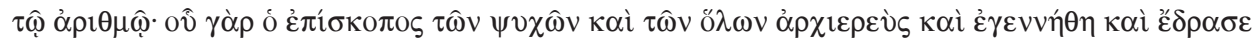

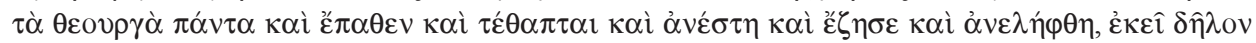

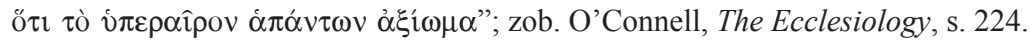

${ }^{96}$ Por. tenże, Epistula 276.

${ }^{97}$ Por. O'Connell, The Ecclesiology, s. 226-227; zob. Gardner, Theodore of Studium, s. 115-129.

${ }^{98}$ Por. A. Papadakis - J. Meyendorff, The Christian East and the Rise of the Papacy, Crestwood 1994, 158-160.

${ }^{99}$ Por. J. Herrin, The Foundation of Christendom, Princeton 1987, 104-105.

${ }^{100}$ P. Hughes, The Church in Crisis: A History of the General Councils 325-1870, New York 1961, 15.

${ }^{101}$ Por. M. Whelton, Popes and patriarchs: an Orthodox perspective on Roman Catholic claims, Ben Lomond 2006, 81-82.

${ }^{102}$ Por. Whelton, Popes and patriarchs, s. 83. 
nie przyjętą zasadę regionalnego pierwszeństwa pewnego Kościoła lokalnego. Szczególnie uznaje wywyższony status biskupów Rzymu, Aleksandrii i Antiochii nad innymi biskupami na określonym terytorium ${ }^{103}$. Kanony soborowe odzwierciedlają zasadę, zgodnie z którą świecka ważność pewnego miasta stanowi o eklezjalnej ważności biskupa tego miasta ${ }^{104}$. Sobór Nicejski I (325) wyróżnił także stolicę biskupią w Jerozolimie, nadając jej tylko pierwszeństwo honorowe $(\tau \hat{\eta} \varsigma \tau \imath \mu \hat{\eta} \varsigma)^{105}$. Nie oznaczało to jednak pierwszeństwa jurysdykcyjnego nad Cezareą, która nadal pozostała stolicą metropolitalną, a Jerozolima - sufraganią ${ }^{106}$.

Sobór Konstantynopolitański I (381) uzupełnił w tym zakresie dekrety Soboru Nicejskiego. Według nauczania soboru jurysdykcję kościelną należy uporządkować według jurysdykcji państwowej i znaczenia politycznego miast ${ }^{107}$. Aleksandria została pozbawiona pierwszeństwa na Wschodzie, a otrzymał je Konstantynopol, Nowy Rzym ${ }^{108}$. Chociaż w kanonach tego soboru mówi się o pierwszeństwie honorowym ( $\tau \dot{\alpha} \pi \rho \varepsilon \sigma \beta \varepsilon \hat{\imath} \alpha \tau \hat{\eta} \varsigma \tau \imath \mu \hat{\eta} \varsigma$ ), to jednak w rzeczywistości chodzi o pierwszeństwo jurysdykcyjne ${ }^{109}$. Podstawą nadania pierwszeństwa było polityczne znaczenie miasta. Pierwszeństwo Rzymu oparte na „apostolskości” Piotra nie było zwalczane, ale nie zostało też wspomniane ${ }^{110}$.

Potwierdzenie i uzupełnienie pierwszeństwa poszczególnych patriarchatów miało miejsce na Soborze Chalcedońskim w 451 r.. Sobór nadał biskupowi Konstantynopola te same prerogatywy, którymi cieszył się biskup Rzymu. Według Ojców Soborowych Konstantynopol powinien zostać wywyższony do godności Starego Rzymu w aspekcie eklezjalnym i zająć drugie miejsce po

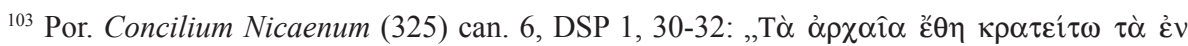

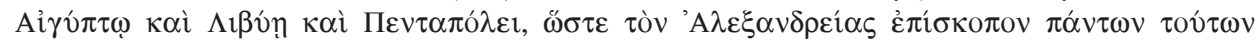

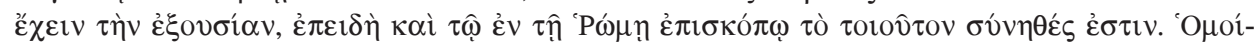

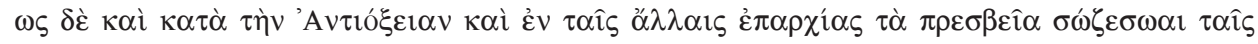
$\dot{\varepsilon} \kappa \lambda \kappa \lambda \eta \sigma i \alpha ı \varsigma^{\prime}$. Zob. Przekop, Wschodnie patriarchaty, s. 27-28.

${ }^{104}$ Por. L.J. Patsavos, Primacy and Conciliarity: Studies in the Primacy of the See of Constantinople and the Synodal Structure of the Orthodox Church, Brookline 1995, 1-2; F.J. Marini, The Power of the Patriarch. An Historical-Juridical Study of Canon 78 of the Codex Canonum Ecclesiarum Orientalium, Roma 1994, 28-30.

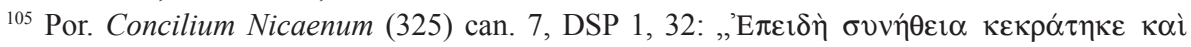

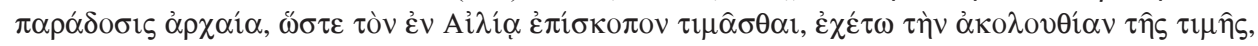

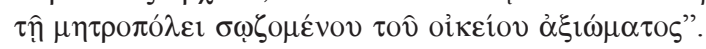

${ }^{106}$ Por. Marini, The Power, s. 39.

${ }^{107}$ Por. Concilium Constantinopolitanum (381) can. 2, DSP 1, 70-72. Zob. Marini, The Power, s. 40; H. Chadwick, The Early Church, London 1993, 151.

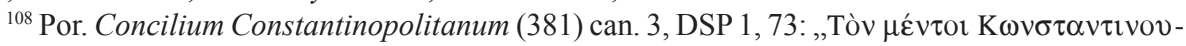

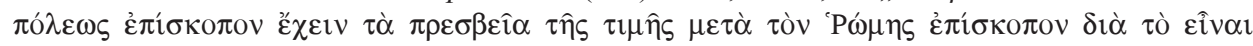

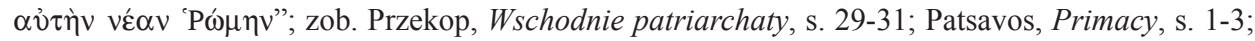
Whelton, Popes and Patriarchs, s. 85-87.

${ }^{109}$ Por. Marini, The Power, s. 39-40.

${ }^{110}$ Por. tamże, s. 40 i 48-49; Patsavos, Primacy, s. 9-10. 
Starym Rzymie ${ }^{111}$. Generalnie przyjmuje się, że przywileje Konstantynopola już istniały w praktyce, a sobór tylko je uznał ${ }^{112}$. Konstantynopol, który na początku był biskupstwem metropolii w Heraklei, od V w. praktycznie był uznawany za centrum patriarchalne i drugą stolicę w Kościele ${ }^{113}$.

Na soborze w Chalcedonie biskupstwo Jerozolimy zostało wywyższone do rangi patriarchatu. Biskup Juwenal z Jerozolimy (420-458) zdołał doprowadzić do zmiany honorowego statusu Jerozolimy na status patriarchatu ${ }^{114}$. Nowy patriarchat w Jerozolimie nigdy jednak nie miał takiego wpływu jak Aleksandria i Antiochia ${ }^{115}$.

Generalnie przyjmuje się cztery kryteria, które zadecydowały o statusie patriarchalnym poszczególnych biskupstw: 1) charakter sakralny (Jerozolima);2) apostolskie pochodzenie (Rzym, Aleksandria, Antiochia); 3) ważne centrum, z którego chrześcijaństwo rozprzestrzenia się na inne obszary (Aleksandria, Antiochia); 4) dominacja polityczno-społeczna (Rzym, Konstantynopol) ${ }^{116}$.

W czasach cesarza Justyniana I (527-565) całe ustawodawstwo eklezjalnocywilne było oparte na idei pięciu patriarchatów, które wyrażały cały Kościół. Właśnie cesarz Justynian jako pierwszy używał terminu ,patriarcha” w tym kontekście. Od czasów Justyniana termin „,patriarcha” był zarezerwowany dla zwierzchników pięciu wielkich stolic eklezjalnych ${ }^{117}$. W ustawodawstwie

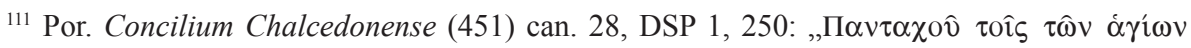

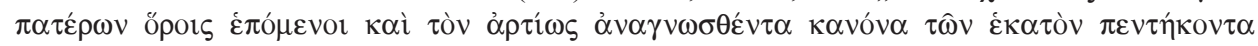

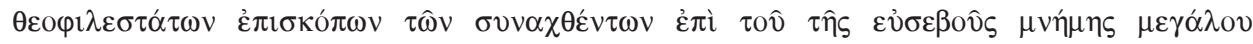

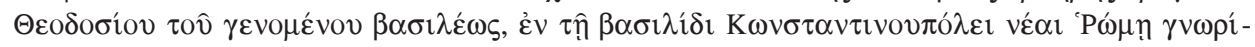

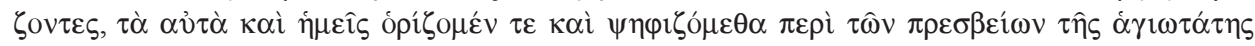

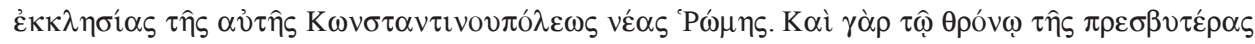

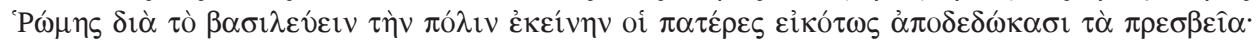

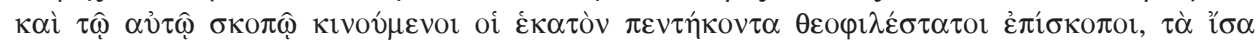

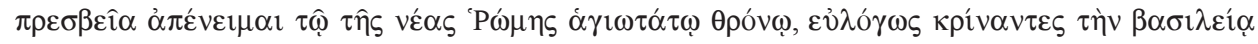

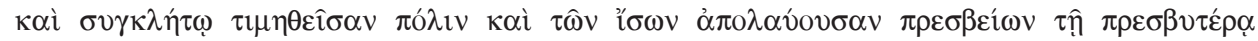

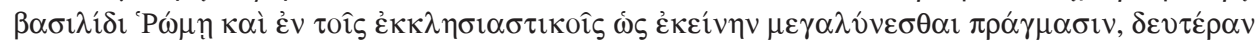

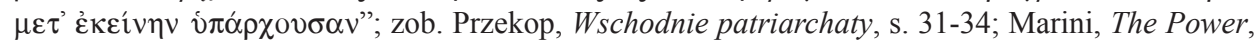
s. 48-49; Hughes, The Church, s. 87.

112 Por. Marini, The Power, s. 51.

${ }^{113}$ Por. S.E. Donlon, Patriarch. Theology and History, w: New Catholic Encyclopedia (= NCE), X, San Francisco - Toronto - London - Sydney 1967, 1092-1093.

${ }^{114}$ Patriarchalny status Jerozolimy nie był omawiany w kanonach soborowych. Sobór jedynie ratyfikował porozumienie zawarte pomiędzy Domnusem z Antiochii a Juwenalisem z Jerozolimy. Jerozolima otrzymała status stolicy patriarchalnej, por. Przekop, Wschodnie patriarchaty, s. 33-34; zob. J.J. McGrath, Patriarchates, NCE X 1096.

${ }^{115}$ Por. O'Connell, The Ecclesiology, s. 29-30.

${ }^{116}$ Por. Donlon, Patriarch, s. 1092-1093; zob. Przekop, Wschodnie patriarchaty, s. 43-62. W celu potwierdzenia własnego autorytetu Konstantynopol do VII w. usiłuje utwierdzić ideę o apostolskim pochodzeniu tej stolicy, por. O'Connell, The Ecclesiology, s. 33-34.

${ }^{117}$ Iustinianus, Corpus iuris civilis, Novella 123, 3, ed. D. Godefroy: Les Novelles de l'empereur Justinien, II, Metz 1811, 181: „Iubemus igitur beatissimos quidem archiepiscopos et patriarchas, 
Justyniana termin ,patriarcha” nabiera technicznego znaczenia na określenie biskupa zarządzającego terytorium i poddanego tylko patriarsze $\mathrm{Rzymu}^{118}$. Justynian podkreśla pozycję Rzymu jako pierwszego patriarchatu ${ }^{119}$. Cesarz Justynian uważał obecność pięciu patriarchów za istotną dla zebrania ekumenicznego soboru, nie ujmując nic pierwszeństwu Rzymu, który nadal pozostał przewodniczącym całego Kościoła i był kluczem jedności kościelnej ${ }^{120}$.

Po Justynianie idea pentarchii stała się częścią teologicznego światopoglądu Bizancjum. Świadczy o tym Żywot patriarchy Eutychiusza, napisany przez kapłana Eustracjusza ok. 583 roku. Eustracjusz w kontekście Soboru Konstantynopolitańskiego II (553) pisze, że stało się godne podziwu wydarzenie, które ani nigdy przedtem nie miało miejsca, ani nie będzie miało miejsca w przyszłości, ponieważ na jednym soborze zebrali się razem czterej patriarchowie (za wyjątkiem jerozolimskiego) i w ten sposób w Kościele zapanował pokój ${ }^{121}$.

hoc est senioris Romae et Constantinopoleos, et Alexandriae, et Theopoleos, et Hierosolymorum, [...]"; tamże 109, Praefatio, ed. Godefroy, s. 101: ,[...] membrum sanctae Dei catholicae et apostolicae ecclesiae, in qua omnes concorditer sanctissimi [episcopi et] totius orbis terrarum patriarchae, et Hesperiae Romae et huius regiae civitatis et Alexandriae et Theopoleos et Hierosolymorum, et omnes qui sub eis constituti sunt, sanctissimi episcopi, apostolicam praedicant fidem atque traditionem"; zob. Donlon, Patriarch, kol. 1092-1093.

${ }^{118}$ M.J. Higgins, Patriarchate, Byzantine. Pentarchy, NCE X 1094.

${ }^{119}$ Iustinianus, Corpus iuris civilis, Novella 131, 2, ed. Godefroy, s. 241: „Ideoque sancimus secundum earum definitiones sanctissimum senioris Romae papam primum esse omnium sacerdotum, beatissimum autem archiepiscopum Constantinopoleos Novae Romae secundum habere locum post sanctam apostolicam sedem senioris Romae, aliis autem omnibus sedibus praeponatur".

${ }^{120}$ Por. O'Connell, The Ecclesiology, s. 33-34.

${ }^{121}$ Por. Eustratius, Magni et Beatissimi Eutychii Patriarchae Constantinopolitani Vita et Con-

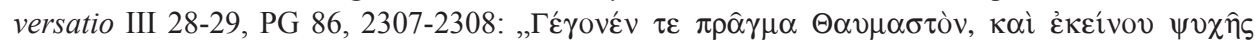

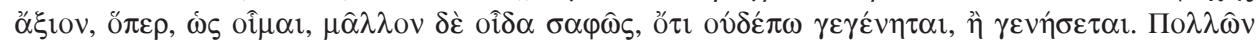

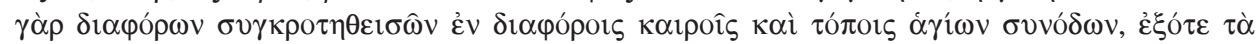

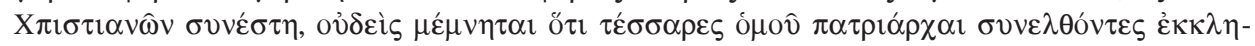

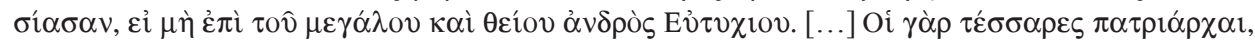

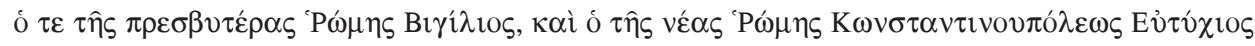

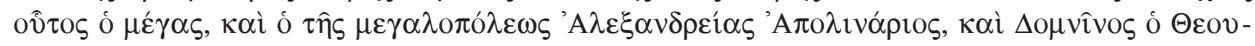

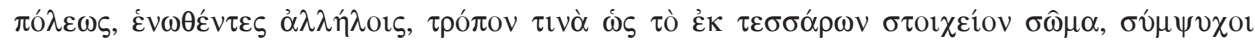

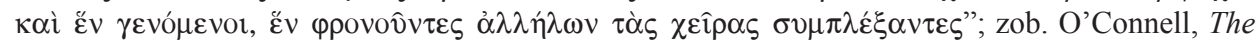
Ecclesiology, s. 33; Higgins, Patriarchate, kol. 1094. Na soborze w Konstantynopolu w rzeczywistości byli obecni: Eutychiusz z Konstantynopola, Apolinariusz z Aleksnadrii, Domninus z Antiochii i trzej biskupi, którzy reprezentowali niedawno wybranego Eustachiusza z Jerozolimy, zob. F.X. Murphy, Constantinople II, Council of, NCE IV 238-240. Jeśli chodzi o papieża, to był on w tym czasie obecny w Konstantynopolu, przyprowadzony przymusem przez cesarza Justyniana. Nie uczestniczył on jednak w posiedzeniach soborowych z powodu konfliktu z cesarzem, ponieważ nie chciał potępić Trzech Rozdziałów w taki sposób, jak tego wymagał cesarz. Jednak w grudniu 553 r. papież Wigiliusz zaakceptował potępienie Trzech Rozdziałów, por. Hughes, The Church, s. 110-119. 
W czasach Soboru Konstantynopolitańskiego III (680) zgoda pięciu patriarchów stała się decydującym argumentem dla określenia przedmiotu wiary, a jedność z patriarchami - potwierdzeniem jedności z Kościołem Katolickim. Świadczy o tym stanowisko św. Maksyma Wyznawcy. Według niego synod monoteletów zwołany w 639 r. przez Pyrrusa nie jest soborem, a jego decyzje nie są zobowiązujące, ponieważ nie uczestniczyli w nim patriarchowie ani osobiście, ani nie byli reprezentowani przez przedstawicieli ${ }^{122}$. W tym miejscu warto podkreślić argument, że sobór powszechny nie może odbyć się bez obecności na nim wszystkich Kościołów, reprezentowanych przez patriarchów. Według św. Maksyma Rzym ma szczególne miejsce jako podstawa i fundacja Kościołów Bożych ${ }^{123}$.

Idea pentarchii znajduje swoje dopełnienie w dekretach synodu Quinisextum (691-692), który jest źródłem potwierdzającym istnienie instytucji pentarchicznej. Synod potwierdził zrównanie przywilejów stolicy konstantynopolitańskiej ze stolicą w Starym Rzymie. Konstantynopol zajmuje drugie miejsce po Rzymie. W dalszej kolejności następują po sobie Aleksandria, Antiochia i Jerozolima. Poprzednie sobory mówią o biskupstwach i miastach, a ten synod mówi o stolicach ( $\theta \rho o ́ v o r)^{124}$.

Na przełomie VIII i IX w. dojrzałą ideę pentarchii znajdujemy u konstantynopolitańskiego patriarchy Nikefora. Nauczał on o równości wszystkich pięciu patriarchów i twierdził, że w pentarchii nie daje się pierwszeństwa którejś z patriarszych stolic, natomiast wszyscy patriarchowie pełnią przywódczą rolę. Jednomyślność i wspólny osąd patriarchów wyrażają jedność Kościoła opartą na wspólnej regule wiary. Jest to kryterium kanoniczności soboru powszechnego. Nikefor w swoich rozważaniach zastanawia się nad teoretyczną opcją objęcia stolicy patriarszej przez heretyka. W takim przypadku, dowodzi,

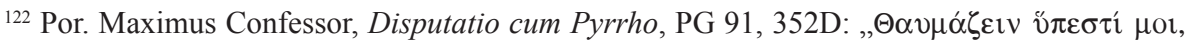

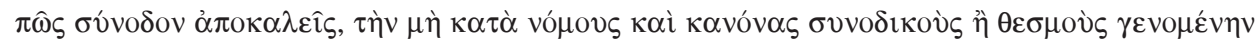

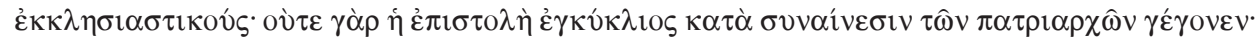

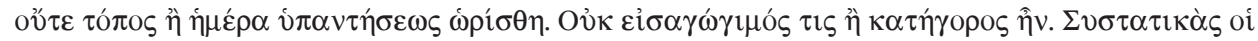

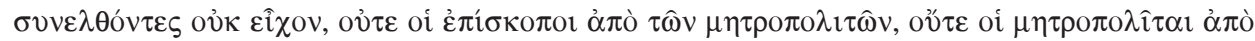

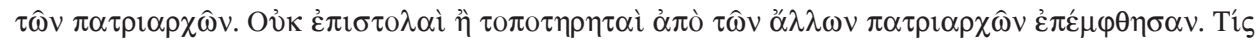

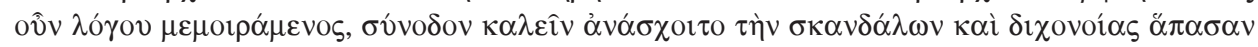

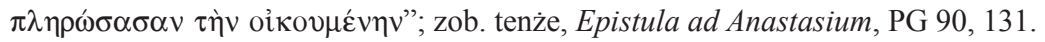

${ }^{123}$ Por. tenże, Ex epistula Romae scripta, PG 91, 137-140; tenże, Deploratio 74 ex epistula scripta ad Petrum illustrem, PG 91, 144.

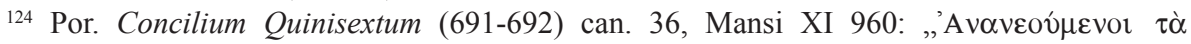

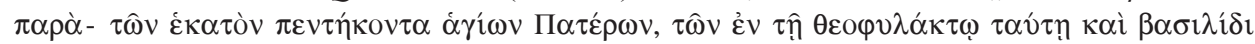

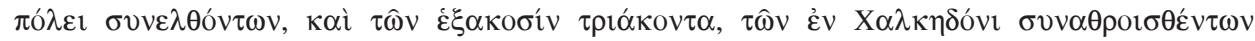

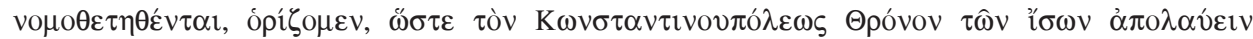

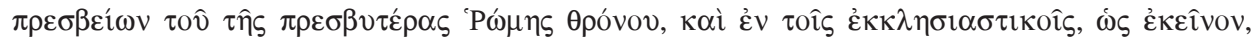

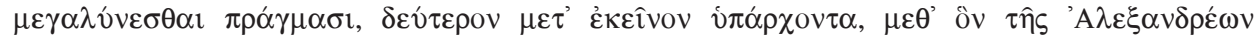

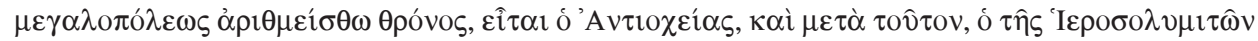

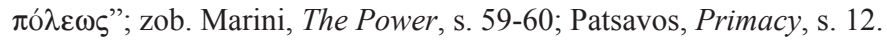


wystarczy porozumienie pozostałych czterech patriarchów, żeby pozbawić go władzy. Jeżeli zaś nie udaje się dojść do zgody pomiędzy patriarchami, wtedy należy przyjąć wyjaśnienie od stolicy rzymskiej, która stanowi rękojmię ortodoksyjności. Patriarcha Rzymu według Nikefora ma takie prerogatywy w Kościele, jakie miał apostoł Piotr w kolegium apostolskim ${ }^{125}$.

Podsumowując należy stwierdzić, że w czasach Teodora Studyty idea pentarchii była wyrazem kościelnej jedności w określaniu doktryny zgodnej z Tradycją Ojców. W pentarchii wyrażają się trzy kluczowe idee - jedność, powszechność i apostolskość ${ }^{126}$. Wierzono, że kwestie wiary należy rozstrzygać na soborze powszechnym, który nie może być uznany za kanoniczny bez zgody pięciu patriarchów. Najważniejszą rolę na soborze pełni patriarcha Rzymu, jednak nie w izolacji od innych patriarchatów, a w jednomyślności i porozumieniu z nimi. Należy jednak przyznać, że przed podbojem arabskim idea pentarchii była praktyką bez odpowiedniej teorii, natomiast $\mathrm{w}$ dobie ikonoklazmu stała się teorią bez możliwej praktyki: pozycja Aleksandrii i Antiochii została znacznie osłabiona w ciagu V i VI w. w wyniku sporów nestoriańskich i monofizyckich; ponadto podboje arabskie w VII w. osłabiły Aleksandrię, Antiochię i Jerozolimę ${ }^{127}$. Najbardziej wpływowymi chrześcijańskimi centrami pozostały jedynie Rzym i Konstantynopol. Jeżeli Konstantynopol z różnych racji wiązał się z nauczaniem heterodoksyjnym, to jedynym punktem odniesienia pozostawał Rzym.

$* * *$

Od 1. poł. VIII aż do poł. IX w. Kościół konstantynopolitański zmagał się z heretyckim ruchem ikonoklastycznym. W dobie ikonoklazmu po stronie obrońców kultu obrazów pojawił się wielki myśliciel - św. Teodor Studyta (759-826), opat klasztoru Studion koło Konstantynopola. Jednym z głównych tematów poruszanych przez niego stała się niezależność Kościoła od władzy świeckiej, która interweniowała w określanie kwestii dotyczących wiary i obyczajów. Sw. Teodor Studyta pragnął udowodnić, że dogmaty i reguły Kościoła pochodzą nie od cesarzy, lecz od biskupów. W tym kontekście zaczyna się kreować idea pentarchii. Według św. Teodora rękojmię ortodoksyjności, która jest podstawąjedności Kościoła powszechnego, stanowi eklezjalny organ pentarchii. Rozstrzyganie o chrześcijańskich dogmatach, sprawach dotyczących wiary i moralności, zostało powierzone pięciu patriarchom, którzy powinni odznaczać się jednomyślnością, aby dojść do wspólnej decyzji na soborze. Wszyscy razem mają najwyższy osąd w Kościele a ich zgoda jest konieczna dla uznania soboru powszechnego. W orbicie pentarchii uprzywilejowane sta-

\footnotetext{
${ }^{125}$ Por. O’Connell, The Ecclesiology, s. 108-194.

${ }^{126}$ Por. tamże, s. 36.

${ }^{127}$ Por. Patsavos, Primacy, s. 12; Dagron, Ikonoklazm, s. 134; O'Connell, The Ecclesiology, s. 30.
} 
nowisko zajmuje patriarcha Rzymu, bez którego nie może odbyć się żaden sobór powszechny. Kościół rzymski jest punktem odniesienia, centrum jedności Kościoła. Św. Teodor Studyta rozpatruje pierwszeństwo biskupa Rzymu nie w izolacji od innych patriarchatów, lecz w orbicie całego Kościoła.

\section{THE IDEA OF PENTARCHY AS THE GUARANTEE OF CHURCH UNITY DURING ICONOCLASTIC PERIOD. THE POSITION OF ST. THEODORE OF STUDIUM}

(Summary)

From the first half of the eighth century until the mid-ninth century the Church of Constantinople struggled with heretical iconoclast movement. During the period of iconoclasm, St. Theodore of Studium (759-826) stood at the side of the defenders of the cult of images. He was a great thinker and abbot of the Studium monastery near Constantinople. One of the main themes he discussed was an independant status of Church from secular power, which frequently intervened in issues relating to faith and morals. St. Theodore of Studium wanted to prove that the Church dogmas and rules derive not from emperors, but bishops. In this context, his idea resembles the concept of pentarchy. According to St. Theodore, the guarantee of orthodoxy, which is the basis for the unity of the universal Church, is rooted in ecclesial body of pentarchy. Decisions about divine and celestial dogmas are entrusted to five patriarchs, who should be characterized by unanimity to reach a joint decision at the universal council. All of them together have the highest position in the Church and their consent is necessary for recognition of the ecumenical council. Among the five patriarchs the privileged position has the patriarch of Rome, without whom no ecumenical council can be called. The Roman Church is the reference point and stands at the center of the unity of Church. St. Theodore of Studium considered the primacy of the bishop of Rome not in isolation from other patriarchates but in orbit of the entire Church. 